\title{
Drug resistance in multiple myeloma: latest findings and new concepts on molecular mechanisms
}

\author{
Jahangir Abdi ${ }^{1,2}$, Guoan Chen ${ }^{3}$, Hong Chang ${ }^{1,2,4}$ \\ 1 Division of Immunopharmacology, Utrecht Institute for Pharmaceutical Sciences, Utrecht University, Utrecht, The \\ Netherlands \\ 2 Dept. of Laboratory Hematology, University Health Network, Toronto, Ontario, Canada \\ ${ }^{3}$ Dept. of Hematology \& Oncology, The First Affiliated Hospital of Nanchang University, Nanchang, China \\ ${ }^{4}$ Division of Molecular and Cellular Biology, Toronto General Research Institute; Toronto, Ontario, Canada \\ Correspondence to: Hong Chang, email: Hong.Chang@uhn.on.ca \\ Keywords: multiple myeloma, drug resistance, signaling pathways, oncogenes \\ Received: October 13, $2013 \quad$ Accepted: November 22, 2013 \\ Published: November 24, 2013
}

This is an open-access article distributed under the terms of the Creative Commons Attribution License, which permits unrestricted use, distribution, and reproduction in any medium, provided the original author and source are credited.

\section{ABSTRACT:}

In the era of new and mostly effective therapeutic protocols, multiple myeloma still tends to be a hard-to-treat hematologic cancer. This hallmark of the disease is in fact a sequel to drug resistant phenotypes persisting initially or emerging in the course of treatment. Furthermore, the heterogeneous nature of multiple myeloma makes treating patients with the same drug challenging because finding a drugable oncogenic process common to all patients is not yet feasible, while our current knowledge of genetic/epigenetic basis of multiple myeloma pathogenesis is outstanding. Nonetheless, bone marrow microenvironment components are well known as playing critical roles in myeloma tumor cell survival and environmentmediated drug resistance happening most possibly in all myeloma patients. Generally speaking, however; real mechanisms underlying drug resistance in multiple myeloma are not completely understood. The present review will discuss the latest findings and concepts in this regard. It reviews the association of important chromosomal translocations, oncogenes (e.g. TP53) mutations and deranged signaling pathways (e.g. NFKB) with drug response in clinical and experimental investigations. It will also highlight how bone marrow microenvironment signals (Wnt, Notch) and myeloma cancer stem cells could contribute to drug resistance in multiple myeloma.

\section{INTRODUCTION}

Multiple myeloma (MM) is the second most common but as yet incurable hematologic malignancy characterized by infiltration in the bone marrow of malignant plasma cells. MM is usually preceded by a pre-malignant stage termed monoclonal gammopathy of undetermined clinical significance (MGUS) which progresses to overt MM at a rate of $0.5 \%$ to $3 \%$ per year [1]. The major clinical manifestations are the outcome of tumor expansion and survival within the bone marrow and resistance to chemotherapy as the final sequel. Basically MM displays a complicated karyotype and high level of genomic/chromosomal instability associated with various gene mutations and chromosomal translocations [1]. On the other hand, oncogenomics studies have found only a few differences that distinguish MM from MGUS [2], because both conditions can present either a hyperdiploid karyotype or a non-hyperdiploid karyotype [3] and similar IgH or IgL chromosomal translocations [4], implying that most above genetic changes may not contribute to MM progression. MM pathogenesis can also be largely explained on the basis of interaction of MM cells with bone marrow microenvironment (BMME) components and signaling pathways thereof leading to $\mathrm{MM}$ cells growth and survival, angiogenesis, osteolytic lesions and drug resistance (DR). In this respect, a variety of candidates (genes/proteins) have been identified mostly 
through gene expression profiling (GEP) studies, which include heat shock proteins (HSPs), some miRNAs, c-MAF, NFкB, Notch and Wnts and their relevant signaling pathways. Perhaps the main feature of these pathways which has made them attractive drug targets is that they are mostly active in MM cells in the context of BMME hence contributing to various aspects of MM pathology especially DR. Furthermore, the new concept of MM cancer stem cell (MMCSC) indicates involvement of Notch and Wnt signaling pathways in biology of this "MM-initiating" cell which takes advantage of bone marrow stromal cells (BMSCs) protection, and indeed new efforts on targeting MMCSC are ongoing [5].

\section{Drug resistance in malignancies: general concepts}

Chemotherapy refractoriness tends to be a clinical frustration in blood cancers and a variety of solid tumors including breast, ovarian, lung, and lower gastrointestinal tract cancers [6-8]. During the past decades, multitudes of mechanisms have been suggested for this DR. For example, drug may be prevented from entering the cells or be pumped out of the cells; it may become enzymatically inactive, mutation or alteration in expression of the drug target, and derangement in mechanisms of apoptosis, senescence and DNA repair could also contribute to DR. Likewise, in hematologic malignancies DR eventually happens although most acute leukemias respond efficiently to chemotherapy at the beginning [8]. Basically, malignant tissues consist of a heterogeneous population of cells with different levels of sensitivity to chemotherapy [7, $9,10]$. Some of these cells may be easily eliminated by the drug while others may become totally resistant. This is in clear contrast to normal cells which usually respond homogeneously to the chemotherapeutic drug. In most cases, malignant cells may become resistant to a single drug in which case DR can be circumvented by using a combination of structurally and functionally different chemotherapeutic drugs. However, cancer cells may also become cross-resistant to various drugs leading to a situation known as multiple drug resistance (MDR). The main mechanism controlling MDR is overexpression of an ATP-dependent efflux pump known as P-gp [11]. This $170 \mathrm{KD}$ protein is encoded in humans by MDR 1 gene and is the first known member of ABC (ATP-binding cassette) transporter superfamily. In MDR phenotypes, P-gp is overexpressed and through pumping the drug out of the cells reduces the intracellular concentration of the drug below minimum threshold for effective response, hence rendering cancer cells drug resistant. Other members of transporter superfamily include multi-drug resistance protein-1 (MRP-1), lung resistance related protein (LRP) and breast cancer resistance protein (BCRP). P-gp, MRP1 and LRP have been found upregulated and associated with DR in acute lymphoid and myeloid leukemia patients leading to those markers being used as targets for MDR modulation [12]. In MDR, it appears that mechanisms controlling drug accumulation inside the cells are defective, most possibly through altering membrane lipids (ceramides) which in turn limit drug uptake or increase drug efflux [13]. Interestingly, sphingosine-1-phosphate (S1P), a metabolite of ceramide, can confer resistance to drugs in hematologic cancers $[14,15]$. The outcome of above transformations is inhibiting apoptosis (which is normal mechanism of most anti-cancer drugs), limiting normal processes of drug detoxification and DNA repair, and alteration in mechanisms of cell cycle control and check points. It should be noted that gene mutations of drug transporters or drug receptors could also contribute to MDR phenotype $[11,16]$.

Notably, the concept of cancer stem cell (CSC) in both solid and hematologic cancers indicates that "cancer initiating cells" resist chemotherapy due to their ability to self-renew, differentiate and remain relatively quiescent, features in fact hampering the effects of chemotherapeutic cytotoxic drugs which typically target rapidly dividing cells $[10,17]$.

Genetic alterations in signaling pathways downstream to target activation will also have effect on drug response. In most cases, signals will impinge on mutated oncogenes in latter pathways leading to upregulation of survival and drug resistance or downregulation of cell death responses. For example, resistance to Trastuzumab (in treatment of HER-2 positive breast cancer) can be due to upregulation of signaling pathways downstream to HER-2, as a result of PTEN loss, or mutations in PI3K or AKT1 [10]. Genomics technology has now deciphered the impact of somatic mutations on some critical oncoproteins including $R A S, E G F R, B C R$ $A B L$ and many others. These somatic alterations cause the tumors rely unusually on a specific molecular pathway or signaling system. This has been referred to as "oncogene addiction", which is in fact excessive tumor dependence on at least one gain-of-function gene mutation for survival [9].

\section{Drug resistance in multiple myeloma}

In spite of current efficient therapeutic regimens for MM patients, DR is perhaps still the major concern. For instance, bortezomib which continues to be used as a first-in-class drug in MM; many patients may be intrinsically resistant to it or develop resistance in the course of treatment. Although real mechanisms of resistance to bortezomib in $\mathrm{MM}$ patients are not yet deciphered, mutation in $\beta 5$-subunit of proteasome (PSMB5) (conflicting reports), derangement of stress response, survival and antiapoptotic pathways have been indicated to be involved [18]. During the past years many studies were focused on the mechanisms underlying DR 
in $\mathrm{MM}$, and considering the complex and heterogeneous nature of $\mathrm{MM}$ the number of these studies is noticeably increasing. However, with that bulk of research in the past and present, we still don't know exactly how MM progresses from its precursor state, how drug resistant MM clones persist in the presence of effective therapies, and why some MM patients relapse. Here to make a more mechanistic picture of DR in MM based on the most recent findings, we will pursue the discussion covering four categories of explanations: a)-Impact of cytogenetic and epigenetic alterations, b)-Role of deregulated signaling pathways, c)-Role of bone marrow microenvironment, d)MM cancer stem cell.

\section{Impact of cytogenetic and epigenetic alterations}

MM is universally recognized as having a high level of genomic instability and a very complex cytogenetic constitution which is displayed as changes in both number and structure of various chromosomes [19, 20]. Notably, aberrant homologous recombination (HR) has been identified as the main mechanism in MM genome instability which increases overtime contributing to MM aggressiveness and DR [20]. Based on karyotype changes MM patients are placed in two groups: hyperdiploid (HRD) which have 48-75 chromosomes (involving mostly odd-numbered chromosomes 3,5,7,9,11,15,19,21) and non-hyperdiploid (NHRD) which have less than 45 or more than 75 chromosomes and display $\operatorname{IgH}$ translocations or chromosomal deletions such as del (13) [21]. It has been suggested that only $10 \%$ of HRD group show a primary IgH translocation at $14 \mathrm{q} 32$ locus while it amounts to $70 \%$ in NHRD group [21], this might partly explain the better survival and prognosis of HRD group relative to NHRD group. The $\operatorname{IgH}$ translocation usually involves juxtaposition of immunoglobulin gene to an oncogene on partner chromosomes creating several reciprocal translocations, including two more frequent ones $\mathrm{t}(4 ; 14)(\mathrm{p} 16 ; \mathrm{q} 32)$ in $15 \%$ and $\mathrm{t}(11 ; 14)(\mathrm{q} 13 ; \mathrm{q} 32)$ in $17 \%$ of $\mathrm{MM}$ patients [22]. Translocation $\mathrm{t}(4 ; 14)$ deranges at p16 locus the expression of FGFR3 which is a proto-oncogenic receptor tyrosine kinase, and multiple myeloma SET domain (MMSET) which apparently has methyl transferase function [23](readers are also referred to ref. [24] for FGFR3 biologic function). Translocation $\mathrm{t}(11 ; 14)$ causes upregulation of cyclin $\mathrm{D}$ genes which play key role in cell cycle. Of all chromosomal translocations in MM, t(4:14)(p16;q32) has frequently been associated with adverse outcome (and possibly resistance to alkylating agents) in patients under high dose therapy (HDT) modalities or ASCT, but $\mathrm{t}(11 ; 14)$ usually confers a favorable prognosis [25-29]. Of important note, several studies confirm that including bortezomib in the treatment regimen of patients with $\mathrm{t}(4: 14)$ translocation improves and even overcomes the risk factor [30-33].
Less frequent translocations, $\mathrm{t}(14 ; 16)$ and $\mathrm{t}(14 ; 20)$, which upregulate expression of oncogenes c-MAF and MAFB, respectively, have also been associated with MM adverse clinical outcomes [22]. The deletion 17p13 is one of the most important prognostic markers in MM which is observed in $10 \%$ of newly diagnosed patients but increases significantly at later stages [21, 27, 30, 34]. This abnormality is associated with aggressive disease and failed outcome even in the face of novel bortezomib or IMiD-based modalities. In (del) 17p, TP53 heterozygosity is lost leaving it in a monoallelic form. This mechanism in fact limits the key role of p53 in controlling cell cycle and apoptosis and might partly explain the failed treatment. Additional genetic aberrations include c-MYC rearrangements which occur in $15 \%$ of newly diagnosed MM, $40 \%$ of advanced MM tumors and almost $90 \%$ of human myeloma cell lines (HMCLs), indicating that c-MYC overexpression is a marker of MM progression [35-37]. Compared to MM, c-MYC is almost not detected in MGUS [37, 38], and it has also been implicated in DR in $\mathrm{MM}$ [39].

MM patients who relapse or become refractory (primary or after a salvage therapy) carrying any "bad" prognostic cytogenetic marker, might refer with some level of (acquired/intrinsic) drug resistance [40, 41]. While the real impact of cytogenetic aberrations on DR or MM relapse is not mechanistically understood, in some cases experimental studies have yielded helpful clues. For example, in patients with $\mathrm{t}(14 ; 16)$ and $\mathrm{t}(14 ; 20)$ translocations where MAF genes are overexpressed, it was shown that blocking MEK pathway could downregulate MAF, inhibit cell proliferation and sensitize MM cells to the drugs, indicating that MAF exploits a common pathway in both translocations and MEK would be an additional drug target for above patients [42, 43]. Furthermore, $+1 \mathrm{q}$ is found in $39 \%$ of newly diagnosed $\mathrm{MM}$ and in almost $70 \%$ of MM patients harboring $\mathrm{t}(14 ; 16)$ or $\mathrm{t}(4: 14)$ translocations, and has been associated with adverse outcome even in intensively treated patients [33, 44, 45]. Studies have shown that the amplified region in chromosome 1q carries the oncogenes PDZK1 [46] and $C K S 1 B$ [47]. PDZK1 was suggested to be involved in $\mathrm{MM}$ cells resistance to several drugs, as its silencing led to increased drug sensitivity. Surprisingly, PDZK1 was first identified through its interaction with several proteins including MRP2 to make a functional cluster involved in MDR phenotype in cancer cells [48, 49]. CKS1B has also been shown to promote MM cells growth and proliferation [50], and to confer DR through MEK/ ERK and JAK/STAT3 signaling pathways [51]. On the other hand, 1q21 deletion was also found a risk factor independent of CKS1A amplification in MM patients [52]. Moreover, a group of researchers showed that $\mathrm{t}(4: 14)$ and $\mathrm{t}(11 ; 14)$ translocations, which confer different clinical outcomes, contribute to pathologic complications through 
different molecular mechanisms and that they share only few mutated genes [53]. Finally, FGFR3 which is overexpressed in $\mathrm{t}(4: 14)$ translocation was demonstrated to confer resistance to dexamethasone in MM cells [54], and FGFR3 has been used as a drug target in $\mathrm{t}(4: 14)$ positive MM cells [25, 55]. However, another group reported that $\mathrm{t}(4: 14)$ is by itself a risk factor conferring poor drug response independent of FGFR3 expression [25]. Hence, the extent to which above findings can explain DR in relapsed / refractory MM patients with above cytogenetic aberrations is not clear, with most clinical studies suggesting associations (not causes and effects). Nevertheless, gene expression profiling (GEP) and whole genome sequencing (WES) technologies have made possible the establishment of first portraits of gene mutation spectrum and molecular categorization or risk stratification of MM [23, 56-61]. One major goal of these approaches is also finding any collaborative effect of cytogenetic changes and gene mutations on adverse clinical outcome, relapse or DR in MM. TP53 gene mutations are rare in $\mathrm{MM}$ and basically occur at later stages of the disease with strong association with therapy resistance [62-65]. Loss of TP53 locus in MM has been consistently associated with poor survival and resistance to therapy, and with deregulation of various p53 target genes $[34,66]$.

Recent investigations have unraveled substantial contribution of epigenetic changes to hematologic cancers progression and pathogenesis (reviews at [67, $68]$ ). Epigenetic changes in human genome occur in two common forms, DNA methylation and chromatin (histon) modifications (acetylation and deacetylation). But much to our surprise, recognition of abnormal DNA methylation in human cancers has a long history [69]. Basically, DNA methylations occur at $\mathrm{CpG}$ islands of promoters influencing the expression of various genes which in most cases are oncogenes controlling proliferation, apoptosis, DNA repair and drug sensitivity of malignant cells [70]. In spite of extensive investigations on genetic and cytogenetic alterations in MM, our knowledge of the mechanistic role (s) that epigenetic changes might play in MM drug response is limited. Nonetheless, the role of epigenetic markers in MM pathogenesis and MGUS transition to overt MM is increasingly evidenced, with frequency of some hypermethlyated genes being low at early stages but increasing with $\mathrm{MM}$ progression. Using methylation-specific polymerase chain reaction (MSP) most studies have detected hypermethylation of such genes as $p 15, p 16, p 73$ (cell cycle), DAPK, CASP8 (regulation of apoptosis), SOCS1 (cytokine signaling), FHIT1 (tumor suppressor gene), $\mathrm{O}^{6}$-methylguanine DNA methyl transferase or $M G M T$ (DNA repair), TGFBR2 (growth factor receptor signaling) and e-cadherin (cell adhesion) [71-79]. However, latest investigations on MM epigenome using genome-wide methylation arrays have yielded amazing findings shedding more light on epigenetic changes contribution to MM progression and partly DR [80-82]. In these studies, it is shown that the methylation rate increases in transition from MGUS to MM or from MM to plasma cell leukemia (PCL), and that the global methylation pattern in normal B cells, normal plasma cells and MGUS is explicitly hypomethylation. More interestingly, they show that tumor suppressor genes involved in drug response (TGFB1) and interaction with bone marrow microenvironment (SPARC) are hypermethylated and associated with a short OS [81]. In another recent study, researchers tried to find the association between epigenetic changes and pattern of response to bortezomib in relapsed MM patients. Using DNA methylation PCR, they analyzed $\mathrm{CpG}$ island-related DNA methylation profile of 30 genes in 75 relapsed MM patients under bortezomib treatment. They detected a low global methylation status in all patient samples and found that patients with a higher global DNA methylation (more than $3.95 \%$ of total DNA methylated) had higher overall survival (OS) than patients with more unmethylated DNA following bortezomib treatment. Furthermore, in gene-specific methylation they found that patients with lower frequency of methylated $N F K B 1$ and $C X C R 4$ genes had higher OS and progression free survival (PFS), respectively. Also, lower global DNA methylation and higher $N F K B$ methylation pattern conferred a very short OS after bortezomib treatment. Moreover, it has been reported that hypermethylation in $C D K N 2 A, C D K N 2 B$, $T N F$ and $R B$ genes is detected more frequently in relapsed MM patients than newly diagnosed MM patients [83]. Although, in above studies little focus is on the functional and mechanistic aspect of epigenetic changes to MM biology especially in terms of drug response, they convincingly recognize some epigenetic markers as promising drug targets. On the other hand, an association of DNA methylation in MM with drug (dexamethasone) resistance has only been reported in one study [84]. They showed that hypermethylation of RASD1 gene in MM cells was associated with resistance against dexamethasone and treating the cells with 5'-aza-cytidine sensitized the cells to the drug. Additionally, most of above gene methylations have also been reported in acute lymphoid and myeloid leukemias, and methylations of HIC1 and WIT1 were associated with late stage AML and chemotherapy resistant AML, respectively [12]. Indeed some epigenetic markers are being considered as interesting drug targets in hematologic malignancies [85]. It should be noted that histone modifications also have known roles in cancer, but we still don't have sufficient evidence to support role of chromatin changes in MM pathogenesis. However, histone deacetylase inhibitors (HDACi) alone or in combination with chemotherapeutic drugs have always shown profound anti-myeloma activities in both in vitro and in vivo assessments [85-89]. Taken together, how 
epigenetic changes in MM might affect drug response of the patients and whether they play role in DR of MM is not quite understood. One general inference from all above studies could be, at least partially, involvement by epigenetic changes of some pathways controlling cell cycle and proliferation. This idea is rather supported by the study at ref. [90]

\section{Role of deregulated signaling pathways}

To elucidate the biological and biochemical mechanisms underlying DR of MM cells, various researches have been focused on signaling molecules, scaffolds, complexes and mediators in a variety of signaling pathways to reveal targets which could possibly mediate DR following drug treatment. These signaling pathways are mostly involved in two main DR-associated mechanisms: aberrant drug transport, anti-apoptosis.

\section{aberrant drug transport: MDR phenotype}

Overexpression of P-gp, the product of $M D R I$ gene, has frequently been observed in MM and strongly associated with relapse and DR [91-94]. Indeed, several MDR modulators have already been applied to MM clinical trials but were mostly associated with poor benefit due to high toxicity [95-97]. Apparently, polymorphisms in MDR1 gene (SNPs) will also influence therapy outcome, for instance in MM patients under DAV protocol [98], and variously detected in MGUS, MM and relapsed MM tumor cells [99], however, their contribution to bortezomib resistance is not clear [98, 100]. In contrast, a recent study confirms that bortezomib functions as a substrate for P-gp and overexpression of P-gp could underlie bortezomib resistance [101], but this finding is apparently not supported by other studies [18]. Surprisingly, another recent study shows that overexpression of P-gp (ABCB1) defines a subpopulation of MM cells which are resistant to carflizomib, the newly FDA-approved second generation proteasome inhibitor [102]. The major concern with MDR markers is that they are weakly expressed at diagnosis but overexpressed after chemotherapy, for instance, almost $6 \%$ of newly diagnosed MM patients but more than $43 \%$ after chemotherapy (vincristine and doxorubicin) were P-gp positive [94]. Moreover, it has been suggested that following treatment with MDR modulators, tumor cells could upregulate drug target proteins or create mutations abrogating drug-target interaction [97]. The other MDRrelated protein, breast cancer resistance protein (BCRP, ABCG2), seems not to play role in MDR in MM [103], but $A B C G 2$ gene has been found methylatd and upregulated following chemotherapy [104]. On the other hand, a new study on MM cell biology and pathogenesis identified a chromosomal instability (CIN) gene called NEK2 whose overexpression upregulated MDR-related proteins, MDR1 (P-gp), MRP1 and BCRP and was strongly associated with resistance to drugs (bortezomib and doxorubicin), rapid relapse and poor outcome in MM [105].

\section{anti-apoptosis mechanisms}

p53 tumor suppressor protein, known as" guardian of genome", performs an outstanding task in controlling cell cycle, apoptosis, and DNA repair, senescence and autophagy [106-109]. p53 is inactivated in a variety of human cancers, including in $10-12 \%$ of MM tumors mostly due to loss of heterozygocity $[110,111]$. In many cancers, however, p53 inactivation could also be the result of mutations in p53-DNA binding domain or through overexpression of murine double minute 2 (MDM2) [108]. MDM2 is an E3-ubiquitin ligase which binds p53 to ubiquitinate and target it for degradation through ubiquitin/proteasome pathway [112], and is overexpressed in $58 \%$ of MM samples which has been frequently associated with chemoresistance [113, 114]. Of important note, MDM2 in many cancers remains an oncogene even in the face of functional p53, and overexpression of MDM2 in cell lines culminated in resistance to vincristine, doxorubicin and etoposide (e.g. see the ref. [115]). It has also been suggested that MDM2 imposes DR effects through increase in p53 degradation or interaction with MDR1 gene [113]. Another tumor suppressor p14ARF binds to MDM2 and sequesters it in the nucleus to allow p53 stabilization [116]. The regulatory loop p14ARF-MDM2-p53 plays substantial role in cell fate in cases of cellular stresses such as DNA damage (e.g. following chemotherapy) [116]. As happens in MM cells [114], deletion/mutation in p53 or p14ARF (loss of function) or upregulation of MDM2 would direct the pathway toward deregulation of p53-related signaling pathways and downstream targets (p21, GADD45, Bax, Noxa, Puma), hence development of anti-apoptotic and DR signals. Targeting p53 in MM has been considered as an interesting treatment strategy based on mostly restoring p53 function in MM cell lines and primary cells harboring mutated p53. As a nongenotoxic approach, disruption of p53-MDM2 interaction using nutlin-3 or RITA triggered apoptosis in MM cells where synergistic effects with bortezomib were also observed [117-121]. These studies provided evidence that p53 protein and its pro-apoptotic targets Bax, Puma and Bak were upregulated but antiapoptotic Bcl-2 was downregulated following above therapeutic modulation. However, latter findings were not evidenced in primary tumor cells from relapse or refractory MM patients. A recent study demonstrated that inhibition of ubiquitin-specific protease-7 (USP7), which normally stabilizes MDM2, triggers apoptosis in bortezomib-resistant MM cells, confirming the idea of p53 downregulation as a DR mechanism in MM [122]. Involvement of p53 in apoptosis induced by nucleoside analogs (gemicitabin and clofarabin) in MM cells was also shown by another recent study [123]. Several 
proteins have been described with their functions to be p53-dependent, including RPRM (reprimo), a newly identified candidate mediating cell cycle arrest by $\mathrm{p} 53$ [124]. Interestingly, reprimo gene has been reported to be methylated in MM [125]. Two members of p53 family, p63 and p73, bear high level of homology to p53 but their contribution to MM pathogenesis, progression and therapy outcome has not been fully investigated, however, p73 mutations and hypermethylations have been reported in MM cells especially at advanced stages [74]. Furthermore, one study demonstrated accumulation of p63, p73 and p53 in the nuclei of MM cells following drug-induced DNA breaks [126]. Early growth response-1 (EGR1) gene which functions in a p53-dependent manner [127, 128], was shown to mediate $J U N$-induced apoptosis in MM cells and be associated with poor outcome and DR when downregulated [129]. All above studies highlight the key role of p53 and its related proteins in MM pathogenesis and drug response.

The transcription factor $N F \kappa B$ is a well-known player in $\mathrm{MM}$ pathogenesis and biology in terms of tumor cell proliferation, expansion and DR [1, 130, 131], and targeting NFאB pathway in MM (e.g. using bortezomib) has recently improved MM therapy [1, 132]. The contribution of $\mathrm{NF} \kappa \mathrm{B}$ pathway to MM pathogenesis is its constitutive activation in a large proportion of $\mathrm{MM}$ tumor cells and HMCLs mostly due to ligand-dependent activation, including effect of TNF- $\alpha$, TRAIL, BAFF and CD40L on MM cells inside the bone marrow [1]. The latter cytokines are secreted by BMSCs and play critical roles in MM clones maintenance and DR. However, it has recently been discovered that mutations in some genes of NFkB platform result in constitutive activation of NFkB pathway making MM cells less dependent on BMME protection and more refractory to chemotherapy $[56,133,134]$. These findings create novel insights into role of $\mathrm{NF \kappa B}$ pathway activation in $\mathrm{MM}$ pathogenesis but cannot underscore the contribution of extrinsic signals in BMME to NFאB activation-related MM complications especially DR [135] (and see discussion below). Intriguingly, it is also specified that MM cells harboring TRAF3 gene mutation in $\mathrm{NF \kappa B}$ pathway are resistant to dexamethasone but sensitive to bortezomib [133]. This is in line with fact that apoptotic function of bortezomib is partly explained by blocking canonical NFאB pathway; however, it unexpectedly induces the alternative (non-canonical) pathway making MM cells less responsive [136]. Moreover, in some cases MM cells may develop a bortezomib-resistant NFאB phenotype through a proteasome-inhibitor resistant (PIR) pathway [137]. The latter flaws of bortezomib may explain to a large extent why it should be applied in combined regimens for those MM patients who are in relapse or refractory to it. The transcription factor $\mathrm{NF} \kappa \mathrm{B}$ could also contribute to DR in MM through upregulation of some BCL-2 anti-apoptotic family members including BCL-XL [138]. A variety of other molecules and signaling pathways have been implicated in anti-apoptosis or DR mechanisms of MM cells (table 1).

\section{Role of bone marrow microenvironment}

The role of BMME components especially BMSCs and extracellular matrix (ECM) protein in the pathogenesis of MM has been the focus of a good deal of research and to our best knowledge contribution of BMME is noteworthy (reviews at $[1,190,191]$. The fundamental element in this performance is a well-established adhesion between MM cells and BMSCs or fibronectin leading to maintaining the growth, proliferation, invasion and DR of MM clones and also promoting bone lesions and angiogenesis. The best explained mechanisms of MM drug/apoptosis resistance due to BMME effects in MM are soluble factor-mediated drug resistance (SFM-DR) and cell-adhesion mediated drug resistance (CAM-DR) which are in fact two forms of environment-mediated drug resistance (EMDR) in cancers [192]. SFM-DR can be better explained by involvement of IL-6, the most critical growth and survival factor for MM cells, and CAM-DR is mediated by adhesion of MM cells to BMSCs or ECM proteins involving adhesion molecules ( $\beta 1$ integrins). However, other cytokines including HGF [193] and IGF1 [194] have also been implicated in MMDR. It was shown that bortezomib-resistant myeloma cell lines and clinical samples from bortezomib-refractory MM patients displayed an activated IGF-1/IGF-1R signaling pathway and a high level of IGF-1 cytokine which were associated with bortezomib resistance. Blocking IGF-1R or IGF1 signaling alone or synergistically with bortezomib increased MM cells death. Intrinsic (de novo) resistance to drugs including bortezomib may occur in some MM patients, which has been suggested to arise largely due to CAM-DR (a transient form of DR only during cell-cell or cell-ECM adhesion) and more importantly may contribute to emergence of acquired DR in the course of treatment [195]. The same concept has also been supported as an underlying mechanism for de novo DR and minimal residual disease in various cancers $[192,196]$. Following adhesion of MM cells to FN or BMSC, IL-6 is secreted by BMSCs or by MM cells in an autocrine manner [197-199]. IL-6 is certainly the best studied cytokine critical to MM cells, which has been implicated in MM cells resistance to various apoptotic signals including Fas/Apo-1 and chemotherapeutic drugs [200-202], with these responses being possibly controlled through Jak/STAT signaling pathway as was shown in U266 cell line [203]. It has also been demonstrated in MM primary samples that MM cell clones with autocrine IL-6 signal are more resistant to dexamethasone than those with no autocrine IL-6 signal [204]. Additionally, blocking IL-6 receptors with CNTO 328 increased sensitivity of MM cells to bortezomib [205]. These observations highlight the crucial role of IL-6 in anti-apoptosis and DR mechanisms in MM. 
Table 1: Other molecules/pathways with demonstrated roles in MMDR

\begin{tabular}{|c|c|c|c|c|}
\hline Samples analyzed & Molecule/pathway & Alteration pattern & Functional outcome & Refs. \\
\hline $\begin{array}{l}\text { HMCLs, primary cells, } \\
\text { in vivo mouse models }\end{array}$ & $\begin{array}{l}\text { HSPs (HSP90, HSP70, HSP72, } \\
\text { HSP-27, HSF-1) } \\
\text { HSPs function as buffering } \\
\text { systems to safe guard various } \\
\text { client targets (e.g. oncogenes) } \\
\text { and signaling pathways (e.g. } \\
\text { apoptosis) involved in cell } \\
\text { survival. }\end{array}$ & $\begin{array}{l}\text { Overexpression, especially } \\
\text { following adhesion of MM } \\
\text { cells to BMSCs, and possibly } \\
\text { through the effect of } \\
\text { IL-6. }\end{array}$ & $\begin{array}{l}\text { Increase in growth, proliferation, DR, CAM- } \\
\text { DR and resistance to apoptosis mainly } \\
\text { through activated STAT3, NFKB, Akt and } \\
\text { MAPK pathways. Some HSPs (HSP27, } \\
\text { HSP70) are upregulated following treatment } \\
\text { of MM cells with proteasome inhibitors due } \\
\text { to induction of stress response inducing DR } \\
\text { and HSP90 inhibitors show synergism with } \\
\text { bortezomib. In MM, HSPs can also stabilize } \\
\text { antiapoptotic BCL-2 members (BCL-2, MCL- } \\
1 \text { and BCL-XL), as HSP-90 inhibition in U266 } \\
\text { cells resulted in significant apoptosis and } \\
\text { downregulation of above proteins. }\end{array}$ & [139-147] \\
\hline $\begin{array}{l}\text { HMCLs, primary cells, } \\
\text { in vivo mouse models }\end{array}$ & Notch signaling pathway & $\begin{array}{l}\text { Overexpression of Notch } \\
\text { receptors (Notch1) on MM } \\
\text { cells and of Notch ligands } \\
\text { (Jagged-1, Dll1) on BMSCs. } \\
\text { Constitutive activation of the } \\
\text { pathway in BMME. }\end{array}$ & $\begin{array}{l}\text { The Notch1-jagg1 pathway is activated due } \\
\text { to MM cell-BMSC adhesion inducing CAM- } \\
\text { DR. Inhibition of Notch signaling by GSI } \\
\text { ( } \gamma \text {-secretase inhibitor) induces MM cells } \\
\text { apoptosis through upregulation of Noxa. D111 } \\
\text { /Notch pathway also promotes MM cells } \\
\text { resistance to bortezomib through upregulation } \\
\text { of of CYP1A1, a Cytochrome P450 enzyme. } \\
\text { Latter pathway is also constitutively activated } \\
\text { in MMCSCs (CD138- cells) which show more } \\
\text { resistance to drugs than CD138+ cells through } \\
\text { upregulation of BCL-2, MCL-1 and BCL-XL. } \\
\text { Notch pathway may contribute to MMDR } \\
\text { through MM cells-osteoclast interaction. }\end{array}$ & [148-154] \\
\hline HMCLs, primary cells, & Wnt signaling pathway & $\begin{array}{l}\text { Overexpression of Wnt } \\
\text { receptors on MM cells } \\
\text { and, like Notch pathway, } \\
\text { constitutive activation of the } \\
\text { pathway within BMME, partly } \\
\text { due to hypermethylation of } \\
\text { some Wnt antagonists. }\end{array}$ & $\begin{array}{l}\text { Activation of Wnt/ } \beta \text {-catenin (canonical) } \\
\text { pathway in MM cells induces tumor growth, } \\
\text { proliferation and metastatic features, mediates } \\
\text { CAM-DR of MM cells to lenalidomide or } \\
\text { doxorubicin. }\end{array}$ & {$[155-160]$} \\
\hline HMCLs, clinical studies & Cereblon $(\mathrm{CRBN})$ & $\begin{array}{l}\text { Downregulation due to gene } \\
\text { mutation. }\end{array}$ & $\begin{array}{l}\text { First identified as the primary target of } \\
\text { teratogenicity in thalidomide. Associated } \\
\text { with resistance to IMiDs (lenalidomide), high } \\
\text { expression of CRBN is a favourable marker in } \\
\text { MM patients under IMiDs protocol. In a case } \\
\text { study of advanced (extra medullary) MM with } \\
\text { a MDR phenotype, CRBN was found to be } \\
\text { mutated. }\end{array}$ & [161-166] \\
\hline $\begin{array}{l}\text { HMCLs, MM primary } \\
\text { cells, in vivo mouse } \\
\text { models }\end{array}$ & Telomerase & $\begin{array}{l}\text { Hyperactivity of telomerase, } \\
\text { partly due to co-operation of } \\
\text { KRAS and RB1 oncogenes } \\
\text { with telomerase main gene } \\
\text { hTERT. }\end{array}$ & $\begin{array}{l}\text { Maintenance of telomere length leading to } \\
\text { MM cell proliferation, survival and drug } \\
\text { resistance. Hyperactivity of telomerase has } \\
\text { been reported in a large number of relapsed, } \\
\text { refractory or newly diagnosed MM patients, } \\
\text { and was suggested to indicate a poor prognosis. } \\
\text { A possible mediator of bortezomib resistance. }\end{array}$ & {$[167-171]$} \\
\hline $\begin{array}{l}\text { HMCLs, MM primary } \\
\text { cells, in vivo mouse } \\
\text { models, clinical studies }\end{array}$ & miRNAs & $\begin{array}{l}\text { Aberrant expression, up-or- } \\
\text { downregulation, possibly by } \\
\text { epigenetic mechanisms. }\end{array}$ & $\begin{array}{l}\text { Correlation with patient survival. Down-or-up- } \\
\text { regulation of several miRNA (e.g. miRNA-21) } \\
\text { in drug resistant HMCLs compared with } \\
\text { drug sensitive parent lines. Induction of } \\
\text { BMME-related DR by upregulated miRNAs, } \\
\text { miRNA-21,-19a and 19b, or by downregulated } \\
\text { miRNAs, miRNA-15/16a (possibly through } \\
\text { IL-6 upregulation or SOCS1 downregulation). } \\
\text { Overexpression of some oncogenes including } \\
\text { CCDN1, TACC3, MAFB, FGFR3 and MYC } \\
\text { by other downregulated miRNAs (miRNA-425, } \\
\text { miRNA-152, miRNA-24). Inactivation of p53 } \\
\text { protein or its related targets by downregulated } \\
\text { (miRNA-214) or upregulated (miRNA- } \\
\text { 125b/25b/30d and miRNA-181a,b/32) } \\
\text { miRNAs. }\end{array}$ & [172-183] \\
\hline
\end{tabular}




\begin{tabular}{|l|l|l|l|l|}
\hline $\begin{array}{l}\text { HMCLs, MM primary } \\
\text { cells }\end{array}$ & Krüppel-like factor 4 (KLF4) & $\begin{array}{l}\text { Overexpression in MM } \\
\text { patients harboring t(4;14) } \\
\text { (p16.3;q32), not expressed } \\
\text { in HMCLs due to DNA } \\
\text { methylation. }\end{array}$ & $\begin{array}{l}\text { High expression of KLF4 was associated } \\
\text { with upregulation of p27Cip1 abd p27Kip1 } \\
\text { and conferred resistance to melphalan but not } \\
\text { bortezomib. }\end{array}$ \\
\hline $\begin{array}{l}\text { HMCLs, MM primary } \\
\text { cells }\end{array}$ & S1P (Sphingoside-1-phosphate) & Overexpression & $\begin{array}{l}\text { Possibly upregulated by IL-6, S1P confers } \\
\text { antiapoptosis and DR signals through MCL-1 } \\
\text { upregulation. }\end{array}$ & $\begin{array}{l}\text { [14, 15, } \\
185,186]\end{array}$ \\
\hline $\begin{array}{l}\text { HMCLs, MM primary } \\
\text { cells, in vivo mouse } \\
\text { models, clinical studies }\end{array}$ & NEK2 & Overexpression & $\begin{array}{l}\text { Highly correlated with rapid relapse, DR and } \\
\text { poor outcome. Induction of DR mainly through } \\
\text { interaction with drug efflux pumps. }\end{array}$ \\
\hline $\begin{array}{l}\text { HMCLs, patient primary } \\
\text { cells }\end{array}$ & NRAS, KRAS, BRAF & Gene mutation & $\begin{array}{l}\text { Induce DR in MM cells by triggering MAPK/ } \\
\text { ERK pathway }\end{array}$ \\
\hline
\end{tabular}

CAM-DR to doxorubicin, melphalan, vincristine, bortezomib and mitoxantrone has been induced in MM cell lines and patient primary cells through adhesion to FN or BMSCs which was mostly mediated by VLA4 integrin ( $\alpha 4 \beta 1$ ) [206-209] and also through LFA-1 [210]. It should be noted that other integrin molecules including $\beta 7$ and VLA5 ( $\alpha 5 \beta 1)$ could also play role in CAM-DR in MM cells [207, 211]. More importantly, MM primary cells with a higher expression of adhesion molecules (VLA4 and ICAM-1) are drug resistant and believed to be selected by the chemotherapy during treatment tipping contribution to acquired DR by CAM-DR [212]. Of note, acquired $\mathrm{DR}$ is genetically much more complex than de novo $\mathrm{DR}$ (CAM-DR) and indeed takes a long time to emerge. To examine this idea, Hazlehurst et al. induced de novo DR to melphalan in RPMI8226 cell line through adhesion to $\mathrm{FN}$ and also in patient primary cells to confirm the clinical relevance [213]. They then established an acquired melphalan-resistant RPMI8226 subline (RPMI8226-LR5) through long-time drug exposure. Using oligonucleotide microarray, they detected change in the expression of 1479 genes in acquired DR model compared with only 69 genes in de novo DR parent line. These findings strongly indicate that unlike acquired DR which is associated with an outstanding transcriptome change, de novo DR (CAM-DR) is mostly regulated by post transcriptional mechanisms. Indeed, induction of $\beta 1$-integrin mediated CAM-DR in MM cells was characterized by G1 cell cycle arrest accompanied by an increase in $\mathrm{p} 27^{\mathrm{Kip} 1}$ protein level and decrease in enzymatic activity of cyclin A and cyclin E [208], upregulation of $\mathrm{p} 21^{\text {Cip } 1 / \text { Wafl } 1}$ [149] or downregulation of Bim (the apoptotic BCL-2 family member) [213] implying involvement of posttranscriptional mechanisms. Furthermore, adhesion through $\beta 1$ integrin also induces resistance to apoptotic signals such as Fas/Apo-1 in various hematopoietic cancer cell lines including $\mathrm{MM}$ with a post-transcriptionally regulated mechanism. Observations in one study indicated that CAM-DR in MM cells was associated with increase in solubility and redistribution of $\mathrm{c}-\mathrm{FLIP}_{\mathrm{L}}$ allowing its binding to and inhibiting death-inducing signaling complex (DISC) (which forms following CD95 ligation) and thus blocking apoptosis [214].

As a matter of fact in vitro analysis of CAM-DR and
SFM-DR as two separate systems is oversimplification, because it is not unexpected to think that two processes work hand in hand inside the bone marrow (figure 1). In line with this, one study demonstrated the synergistic anti-apoptosis resistance effect of adhesion to FN ( $\beta 1$ integrin signaling) and IL-6 (gp130 signaling) in MM cells associated with activated STAT3 signaling pathway [199]. Moreover, treating MM cells with HGF increased their adhesion to FN which was mediated by VLA4 integrin and PI3K and NFKB pathways implying a synergistic effect of FN-adhesion and HGF in promoting CAM-DR of MM cells [193]. More interestingly, it is suggested that SFM-DR and CAM-DR confer resistance to drug-induced apoptosis in MM cells through distinct mechanisms [215].

However, in recent years many other studies have been focused on deciphering molecular mechanisms of drug/apoptosis resistance in MM conferred by bone marrow stroma. Adhesion of MM cells to BMSCs induces upegulation of Notch receptors on former cells which bind to their specific ligands (Jagged) on latter cells culminating in resistance to drug-induced apoptosis [149]. BMSCs were shown to induce bortezomib-resistant $\mathrm{NF \kappa B}$ activity in MM cells which was mediated by soluble factors including IL-8 from BMSCs [216], providing a supportive explanation to bortezomib resistance in a large number of MM patients [137]. HSPs have also been implicated in CAM-DR of MM, as adhesion of MM cells to BMSCs and FN upregulated HSP-70 in MM cells, and blocking HSP-70 resulted in increase in melphalan-induced apoptosis and reversed CAM-DR [144]. Co-culture of HMCLs (U266 and NCI-H929) with MM patient BMSCs upregulated survivin in MM cells conferring resistance against daunorubicin [217]. Notably, blocking survivin had already been associated with growth inhibition of MM cells and decrease in their resistance to doxorubicin, melphalan and dexamethasone [218]. CD44 the receptor for hyaluronic acid (HA) mediated resistance to lenalidomide in MM cells and lenalidomide-resistant MM cells adhered more strongly to BMSCs and HA implying a role for CD44 in CAM-DR of MM cells [219]. Upregulation of B7-H1 molecule on MM cells following their adhesion to BMSCs was associated with resistance to dexamethasone and melphalan in MM cells and increase in Bcl-2 and FasL levels [220]. Of note, B7-H1 is also 
considered as an immune response evasion tool expressed on malignant plasma cells [221].

Some recent studies have also tried to understand if chromosomal translocations and gene mutations might control interaction of MM cells with BMME components and hence trigger CAM-DR. Knock-down of the MMSET protein in MM cells harboring $t(4 ; 14)$ led to decrease in $\mathrm{MM}$ cell proliferation and induction of apoptosis (activation of caspase-3 and caspase-9) and changed two genes (DSG2 and ADAM9) involved in cell-cell adhesion [222]. Although drug sensitivity of MMSET-silenced MM cells was not examined in this study, their findings imply a possible involvement of MMSET in controlling CAMDR of MM. Using whole exon sequencing (WES), another study detected in MM patient samples and HMCLs somatic mutations in adhesion molecules involved in interaction with BMSCs giving an implication for role of these mutations in CAM-DR, however; no functional experiment was performed [223]. Mutations in some oncogenes including $R A S$ may also affect interaction of MM cells with BMME and hence induce CAM-DR [188]. Furthermore, overexpression of c-MAF was detected in $50 \%$ of MM primary samples and also in HMCLs lacking c-MAF translocations and was associated with increase in $I T G B 7$ (integrin $\beta 7$ ) gene which is involved in adhesion of MM cells to BMSCs and induction of CAMDR [211, 224].

It is interesting to remember that interaction of $\mathrm{MM}$ cells with other cells in BMME could also determine chemoresistance of in MM (figure 1). Osteoclasts confer resistance to doxorubicin-induced apoptosis in $\mathrm{MM}$ cells through secretion of IL-6 and OPN (ostepontin) form osteoclasts. These protective effects were largely dependent on direct cell-cell contact [225]. Contribution to chemoresistance has also been implicated by interaction of MM cells with bone marrow endothelial cells, mainly through induction of cytokines such as IL-6, SDF-1 $\alpha$, MCP-1, Ang-1, bFGF and TNF- $\alpha$ by endothelial cells [226]. Macrophages have been recently implicated in chemoresistance in the context of MM bone marrow environment. These cells also confer resistance to apoptosis induced by dexamethasone and melphalan through direct cell-cell contact and by hampering apoptotic caspase pathway [227] and through adhesion molecules PSGL1/selectins and ICAM-1/CD18 in in vitro and in vivo (SCID mice) via Src, Erk1/2 kinases and c-myc pathways [228]. Some research groups have put forward the role of myeloma bone marrow hypoxia in disease progression and chemoresistance [229]. The mainstay of this concept is that MM bone marrow is more hypoxic than normal

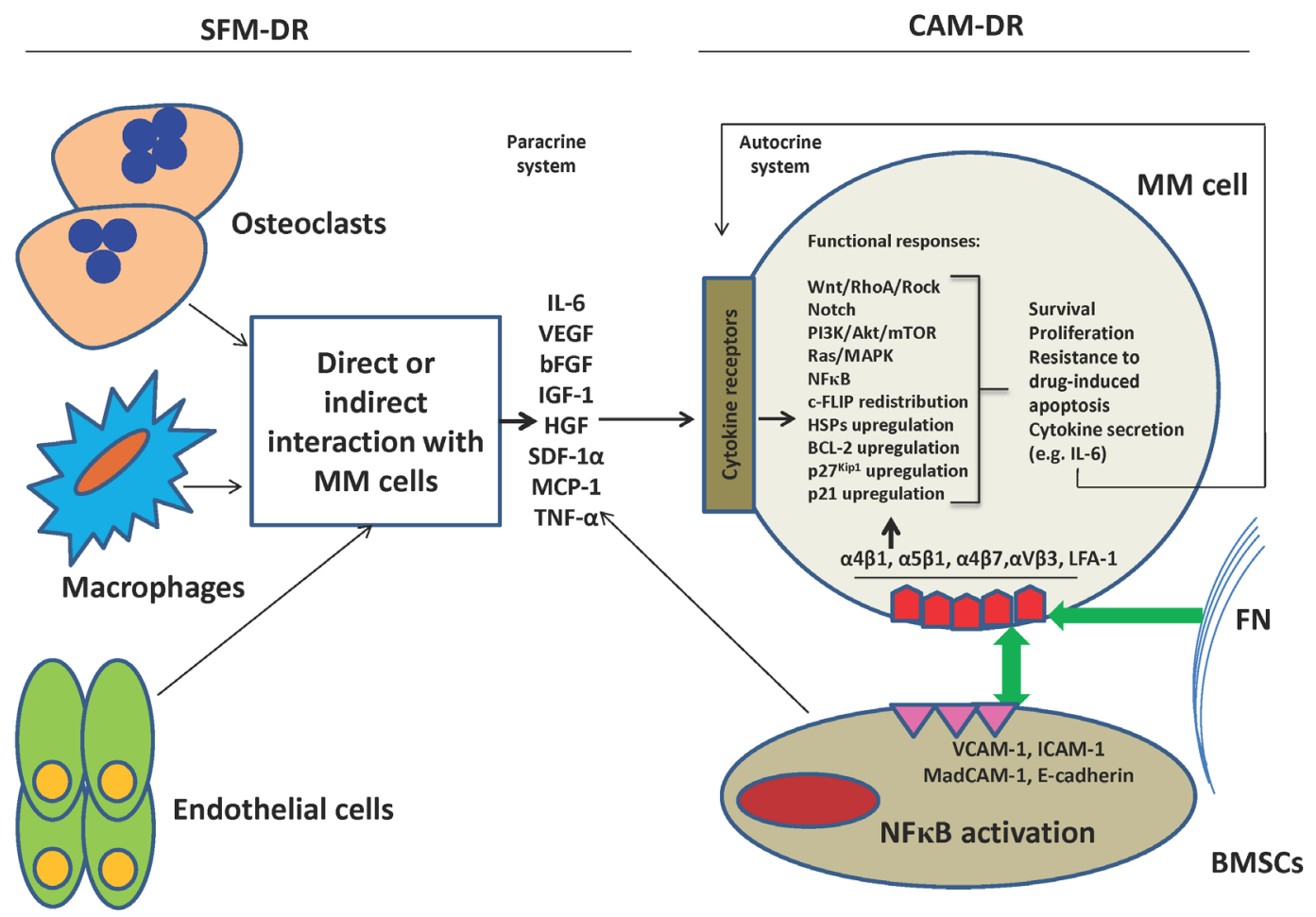

Figure 1: SFM-DR and CAM-DR work usually together within the bone marrow environment. Adhesion of MM cells to BMSCs and FN through integrin molecules triggers a variety of signaling pathways (including Ras/MAPK, PI3K/Akt, NFkB, Notch, Wnt, HSPs) involved in cell proliferation, anti-apoptosis, DR and cytokine secretion (IL-6), and also upregulation of anti-apoptotic BCL-2 family members BCL-2, MCL-1 or BCL-XL. The above adhesion induces secretion of several cytokines (IL-6, VEGF, HGF, IGF-1, SDF$1 \alpha$, TNF- $\alpha$, MCP-1) by BMSCs leading to triggering most of above pathways and induction of resistance to apoptosis and drugs in MM cells (paracrine). IL-6 can also stimulate MM cells in an autocrine manner, although this system has been shown for some other cytokines as well. Furthermore, most above cytokines may also be secreted by osteoclasts, endothelial cells and macrophages during their direct or indirect interactions with MM cells leading to triggering of above functional responses in latter cells 
bone marrow, and this leads to upregulation of HIF- $1 \alpha$ and HIF-2 $\alpha$ which has been associated with suppression of $\mathrm{p} 53$ in some cancer cells, however; this association in MM is not clear yet. Finally, the role of infectious / inflammatory environment of MM cells in disease pathogenesis and DR has recently become an interesting research focus. The first clue of latter concept was expression by MM clinical samples and HMCLs of a wide range of functional Tolllike receptors (TLRs) [230-232]. These molecules belong to a family of pattern recognition receptors which control and integrate immune responses and have been shown to play multiple roles in cancer pathogenesis. Interestingly, stimulating MM cells with some TLR ligands induced secretion of IL-6, dexamethasone resistance, growth and proliferation [231, 232], upregulation of immune evasion markers [221], or differentially modulated expression of adhesion molecules $(\alpha 4, \beta 7$ and $\alpha \mathrm{V} \beta 3)$ and adhesion to FN [233]. On the other hand, stimulation of some TLRs could also trigger apoptosis in some MM cells and sensitize them to bortezomib in FN context [233]. Taken all together, the role that BMME plays in pathogenesis and chemoresistance of MM is undoubtedly vital, to the extent that a plethora of experimental findings pinpoint diverse cellular and molecular mechanisms involved in this BMME-induced protective shield for MM clones.

\section{MM cancer stem cell and DR}

The bulk malignant cells in MM are plasma cells expressing syndcan-1 (CD138), but this marker is pertinent to terminally differentiated cells with limited proliferative potential, and this for many years has led researchers to explore real "MM-initiating cells" or MM cancer stem cells (MMCSCs). Malignant plasma cells in MM harbor somatically hypermutated immunoglobulin genes remaining constant throughout the clinical course of the disease and do not show intraclonal diversity implying that $\mathrm{MM}$ arises from a post-germinal center $\mathrm{B}$ cell having already experienced antigenic challenge in lymph nodes. Generally speaking, the CSC model is based on the concept that cancers constitute a hierarchical organization like the hematopoietic system, suggesting that CSC should maintain cancer cells population through an asymmetric division (each CSC produces a daughter and another CSC).

A convincing line of evidence confirms that MM cells contain a rare subpopulation which is clonotypic and drug resistant, expresses phenotypic markers of memory B cell-like and possess stemness features [5, 234236]. It has been shown that: a)-only CD138- MM cells have the clonogenic potential and are able to propagate MM tumor in NOD/SCID mice, b)-MMCSCs carry the immunophenotype signature CD $138^{-} / \mathrm{CD} 19^{+} / \mathrm{CD} 20^{+} /$ $\mathrm{CD} 27^{+}$, indicating that MMCSCs possess a memory $\mathrm{B}$ cell-like phanotype signature arising from a hierarchical pre-malignant plasma cell stage, c)-In a novel 3D model drug resistant $\mathrm{MM}$ cells were $\mathrm{CD}^{+} 0^{+}$[237], and MMCSCs growth was inhibited by rituximab (anti-CD20 mAb), d)-MMCSCs (CD138- MM cells) are resistant to dexamethasone, lanalidomide, bortezomib, are enriched in a side population (SP) with high ALDH1 activity and drug efflux pump [238], and recently e)-CD138- MM cells are $\mathrm{ALDH}^{+}$, have a higher clonogenic potential than CD138 cells and are able to expand tumor in NOG mice [239]. Several previous studies from Pilarski et al. also confirmed presence of clonotypic B cells in MM patients contributing to tumor expansion, relapse and DR [240-242]. On the contrary, another group of researchers claimed that MM initiating cells were enriched in the CD138-CD19-CD38 ${ }^{++}$ component [243]. They showed that CD19 ${ }^{+}$MM cells could not produce tumor colonies and engraft SCID-rab mice, while these happened only with CD138-CD19$\mathrm{CD}^{2} 8^{++}$, indicating that CD138- MM cells at least in some MM patients are not B cells. Of striking importance, MMCSCs express also functional markers such as drug efflux pumps (ABCC3), ALDH1 and RAR $\alpha 2$ which have been associated with clonogenic potential and resistance to chemotherapy further highlighting their contribution to DR and relapse in MM patients [238, 244, 245]. It was demonstrated that overexpression of $\mathrm{RAR} \alpha 2$ renders MMCSCs (CD138- MM cells) drug resistant by activating ABCC3 gene through stem cell related pathways $\mathrm{Hh}$ (hedgehog) and Wnt. Indeed MMCSCs express mRNA of $\mathrm{Hh}$ receptors which are normally involved in $\mathrm{Hh}$ signaling and regulate homeostasis and biology of normal stem cells [246]. Interestingly, Hh pathway was found active in MMCSCs and blocking this pathway inhibited clonal expansion and induced differentiation. However, activation of this pathway was suggested to be mostly ligand-dependent with BMSCs being the main source of Hh ligands [247], and it can be speculated that interaction of MMCSCs with BMSCs maintains activation of $\mathrm{Hh}$ signaling and tumor dominance. Of note, inhibitors of Hh pathway have already entered clinical trials in MM [248]. Moreover, MMCSCs can also express telomerase which has a prominent role in controlling normal stem cell biology and cancer DR [249]. The inhibitor of telomerase activity Imetelstat blocked MMCSCs clonogenic potential in vitro and in vivo, triggered differentiation of CD138cells into $\mathrm{CD} 138^{+}$cells and decreased the number of $\mathrm{ALDH}^{+}$cells. Taken all together, the above studies provide strong evidence for existence of well-defined stem/progenitor cells possessing the three prominent features common to CSCs in all cancers: self-renewal, proliferation and drug resistance.

\section{MMDR in the face of new therapeutic protocols: can we overcome it?}

Most therapeutic approaches to date for relapsed or refractory MM patients have been based on combined 
formulations. Although emergence of new drugs has revolutionized therapy for MM patients, almost all of them finally develop relapse or DR. As discussed above, using advanced genomics / oncogenomics a variety of factors have been identified to play role in this refractoriness, including various gene mutations, overexpression of MDR genes, epigenetic changes and aberrant activation of various pathways. Importantly, new proteasome inhibitors (including Carfilzomib, ONX 0912, MLN 9708, Marizomib), HDAC inhibitors (e.g. Tipifarnib), new IMiDs (Pomalidomide), kinase inhibitors (especially inhibitors of mTOR and HSP90), new immune-based therapies (antibodies against CS-1, CD38, IL-6) and new alkylators (Bendamustine) have proved effective mostly in combination with conventional drugs in phase I and II clinical trials for MM patients who were bortezomibresistant or in relapse (for reviews see [40, 250, 251]). However, development of DR in these contexts has also been reported necessitating establishment of highly specific targeted therapies. For instance, HSP90 inhibitors prove to be effective with other drugs (including bortezomib), but may induce upregulation of HSP-70 or HSP-27 leading to DR and requires including the inhibitors of latter HSPs [141, 252]. We now know that some genetic alterations detected by oncogenomics with explained roles in MM pathogenesis are also detected in MGUS indicating their poor contribution to disease progression or possibly DR. On the other hand, our knowledge of the role of BMSCs or ECM proteins in MMDR (in terms of their contribution to de novo or acquired DR), and of the nature of MMCSCs has noticeably increased. Therefore, it is expected that new drugs with the specific ability to target these two elements of MM physiology be also developed in order to eradicate MM initiating clones or decrease the chance of DR or relapse. Interestingly, a recent thorough investigation identified CD138- MM cell subsets harboring $\mathrm{Xbp} 1 \mathrm{~s}^{-}$tumor B cells (plausibly MMCSCs) that were bortezomib resistant and targeting latter population has been suggested to be a promising target [253]. Xbp1s has a critical function in B cell development and commitment to plasma cells and is also an important element of unfolded protein response (UPR) in endoplasmic reticulum (ER) stress-related apoptosis.

\section{CONCLUDING REMARKS AND FUTURE PROSPECTS}

Recent progresses in understanding the molecular biology, molecular categorization and therapy of MM patients are certainly amazing. This achievement has been undoubtedly made through precious contribution of advanced technologies such as gene expression profiling (GEP), whole genome sequencing (WGS) or whole exon sequencing (WES), and a tremendous number of in vitro and in vivo investigations. However, MM is still dealt with as a hard to treat hematologic malignancy just due to de novo or acquired DR, indicating that some patients may become initially resistant to the drugs or develop DR in the course of treatment. This will explicitly imply that there still exist complexities in pathogenesis and progression of MM warranting unstoppable research. Nevertheless, identification of a variety of molecules and signaling pathways with different levels of contribution to MM pathogenesis has opened a new horizon to much more targeted therapy than conventional cytotoxic chemotherapy. For the most part, novel insights into role of BMME components especially BMSCs and ECM proteins in $\mathrm{MM}$ pathogenesis, progression and DR, and also increased understanding of nature and role of MMCSCs in tumor expansion and survival have provided us with more promising therapeutic venues to target vital pulses of MM through development of new agents.

\section{ACKNOWLEDGEMENT}

The study was supported in part by the grants from Leukemia \& Lymphoma Society of Canada, Cancer Research Society, International Collaboration Fund from Chinese Ministry of Science and Technology (NO. 2011DFA32820) and Gan-Po 555 project, Jiangxi, China

\section{Conflict of Interest}

The authors declare no conflict of interest

\section{REFERENCES}

1. Anderson KC and Carrasco RD. Pathogenesis of myeloma. Annu Rev Pathol. 2011; 6:249-274.

2. Kyle RA and Rajkumar SV. Monoclonal gammopathy of undetermined significance. Br J Haematol. 2006; 134(6):573-589.

3. Fonseca R, Bailey RJ, Ahmann GJ, Rajkumar SV, Hoyer JD, Lust JA, Kyle RA, Gertz MA, Greipp PR and Dewald GW. Genomic abnormalities in monoclonal gammopathy of undetermined significance. Blood. 2002; 100(4):1417-1424.

4. Zhan F, Huang Y, Colla S, Stewart JP, Hanamura I, Gupta S, Epstein J, Yaccoby S, Sawyer J, Burington B, Anaissie E, Hollmig K, Pineda-Roman M, Tricot G, van Rhee F, Walker R, et al. The molecular classification of multiple myeloma. Blood. 2006; 108(6):2020-2028.

5. Agarwal JR and Matsui W. Multiple myeloma: a paradigm for translation of the cancer stem cell hypothesis. Anticancer Agents Med Chem. 2010; 10(2):116-120.

6. Ullah MF. Cancer multidrug resistance (MDR): a major impediment to effective chemotherapy. Asian Pac J Cancer Prev. 2008; 9(1):1-6.

7. Gottesman MM. Mechanisms of cancer drug resistance. Annu Rev Med. 2002; 53:615-627.

8. Sonneveld P. Multidrug resistance in haematological 
malignancies. J Intern Med. 2000; 247(5):521-534.

9. Garraway LA and Janne PA. Circumventing cancer drug resistance in the era of personalized medicine. Cancer Discov. 2012; 2(3):214-226.

10. Tan DS, Gerlinger M, Teh BT and Swanton C. Anti-cancer drug resistance: understanding the mechanisms through the use of integrative genomics and functional RNA interference. Eur J Cancer. 2010; 46(12):2166-2177.

11. Raaijmakers MH. ATP-binding-cassette transporters in hematopoietic stem cells and their utility as therapeutical targets in acute and chronic myeloid leukemia. Leukemia. 2007; 21(10):2094-2102.

12. Marie JP. Drug resistance in hematologic malignancies. Curr Opin Oncol. 2001; 13(6):463-469.

13. Liu YY, Han TY, Giuliano AE and Cabot MC. Ceramide glycosylation potentiates cellular multidrug resistance. FASEB J. 2001; 15(3):719-730.

14. Wallington-Beddoe CT, Bradstock $\mathrm{KF}$ and Bendall LJ. Oncogenic properties of sphingosine kinases in haematological malignancies. $\mathrm{Br} \mathrm{J}$ Haematol. 2013; 161(5):623-638.

15. Ricci C, Onida F and Ghidoni R. Sphingolipid players in the leukemia arena. Biochim Biophys Acta. 2006; 1758(12):2121-2132.

16. Yang M, Li W, Fan D, Yan Y, Zhang X, Zhang Y and Xiong D. Expression of ABCB5 gene in hematological malignances and its significance. Leuk Lymphoma. 2012; 53(6):1211-1215.

17. Cairo MS, Jordan CT, Maley CC, Chao C, Melnick A, Armstrong SA, Shlomchik W, Molldrem J, Ferrone S, Mackall C, Zitvogel L, Bishop MR, Giralt SA and June $\mathrm{CH}$. NCI first International Workshop on the biology, prevention, and treatment of relapse after allogeneic hematopoietic stem cell transplantation: report from the committee on the biological considerations of hematological relapse following allogeneic stem cell transplantation unrelated to graft-versus-tumor effects: state of the science. Biol Blood Marrow Transplant. 2010; 16(6):709-728.

18. Wang SLaJ. The resistance mechanisms of proteasome inhibitor bortezomib. Biomarker Research. 2013; 1(13):1-9.

19. Walker BA, Leone PE, Chiecchio L, Dickens NJ, Jenner MW, Boyd KD, Johnson DC, Gonzalez D, Dagrada GP, Protheroe RK, Konn ZJ, Stockley DM, Gregory WM, Davies FE, Ross FM and Morgan GJ. A compendium of myeloma-associated chromosomal copy number abnormalities and their prognostic value. Blood. 2010; 116(15):e56-65.

20. Shammas MA, Shmookler Reis RJ, Koley H, Batchu RB, Li C and Munshi NC. Dysfunctional homologous recombination mediates genomic instability and progression in myeloma. Blood. 2009; 113(10):2290-2297.

21. Fonseca R, Bergsagel PL, Drach J, Shaughnessy J, Gutierrez N, Stewart AK, Morgan G, Van Ness B, Chesi M, Minvielle S, Neri A, Barlogie B, Kuehl WM, Liebisch
P, Davies F, Chen-Kiang S, et al. International Myeloma Working Group molecular classification of multiple myeloma: spotlight review. Leukemia. 2009; 23(12):22102221.

22. Boyd KD, Pawlyn C, Morgan GJ and Davies FE. Understanding the molecular biology of myeloma and its therapeutic implications. Expert Rev Hematol. 2012; 5(6):603-617.

23. Zhan F, Hardin J, Kordsmeier B, Bumm K, Zheng M, Tian E, Sanderson R, Yang Y, Wilson C, Zangari M, Anaissie E, Morris C, Muwalla F, van Rhee F, Fassas A, Crowley J, et al. Global gene expression profiling of multiple myeloma, monoclonal gammopathy of undetermined significance, and normal bone marrow plasma cells. Blood. 2002; 99(5):1745-1757.

24. Kalff A and Spencer A. The $t(4 ; 14)$ translocation and FGFR3 overexpression in multiple myeloma: prognostic implications and current clinical strategies. Blood Cancer J. 2012; 2:e89.

25. Keats JJ, Reiman T, Maxwell CA, Taylor BJ, Larratt LM, Mant MJ, Belch AR and Pilarski LM. In multiple myeloma, $\mathrm{t}(4 ; 14)(\mathrm{p} 16 ; \mathrm{q} 32)$ is an adverse prognostic factor irrespective of FGFR3 expression. Blood. 2003; 101(4):1520-1529.

26. Jaksic W, Trudel S, Chang H, Trieu Y, Qi X, Mikhael J, Reece D, Chen C and Stewart AK. Clinical outcomes in $\mathrm{t}(4 ; 14)$ multiple myeloma: a chemotherapy-sensitive disease characterized by rapid relapse and alkylating agent resistance. J Clin Oncol. 2005; 23(28):7069-7073.

27. Fonseca R, Blood E, Rue M, Harrington D, Oken MM, Kyle RA, Dewald GW, Van Ness B, Van Wier SA, Henderson KJ, Bailey RJ and Greipp PR. Clinical and biologic implications of recurrent genomic aberrations in myeloma. Blood. 2003; 101(11):4569-4575.

28. Gertz MA, Lacy MQ, Dispenzieri A, Greipp PR, Litzow MR, Henderson KJ, Van Wier SA, Ahmann GJ and Fonseca R. Clinical implications of $\mathrm{t}(11 ; 14)(\mathrm{q} 13 ; \mathrm{q} 32)$, $\mathrm{t}(4 ; 14)(\mathrm{p} 16.3 ; \mathrm{q} 32)$, and $-17 \mathrm{p} 13$ in myeloma patients treated with high-dose therapy. Blood. 2005; 106(8):2837-2840.

29. Chang H, Sloan S, Li D, Zhuang L, Yi QL, Chen CI, Reece D, Chun K and Keith Stewart A. The t $(4 ; 14)$ is associated with poor prognosis in myeloma patients undergoing autologous stem cell transplant. Br J Haematol. 2004; 125(1):64-68.

30. San Miguel JF, Schlag R, Khuageva NK, Dimopoulos MA, Shpilberg O, Kropff M, Spicka I, Petrucci MT, Palumbo A, Samoilova OS, Dmoszynska A, Abdulkadyrov KM, Schots $\mathrm{R}$, Jiang B, Mateos MV, Anderson KC, et al. Bortezomib plus melphalan and prednisone for initial treatment of multiple myeloma. N Engl J Med. 2008; 359(9):906-917.

31. Avet-Loiseau H, Leleu X, Roussel M, Moreau P, GuerinCharbonnel C, Caillot D, Marit G, Benboubker L, Voillat L, Mathiot C, Kolb B, Macro M, Campion L, Wetterwald M, Stoppa AM, Hulin C, et al. Bortezomib plus dexamethasone induction improves outcome of patients with $\mathrm{t}(4 ; 14)$ myeloma but not outcome of patients with del(17p). J Clin 
Oncol. 2010; 28(30):4630-4634.

32. Chang H, Trieu Y, Qi X, Xu W, Stewart KA and Reece D. Bortezomib therapy response is independent of cytogenetic abnormalities in relapsed/refractory multiple myeloma. Leuk Res. 2007; 31(6):779-782.

33. Chang H, Trieu Y, Qi X, Jiang NN, Xu W and Reece D. Impact of cytogenetics in patients with relapsed or refractory multiple myeloma treated with bortezomib: Adverse effect of 1q21 gains. Leuk Res. 2011; 35(1):95-98.

34. Reece D, Song KW, Fu T, Roland B, Chang H, Horsman DE, Mansoor A, Chen C, Masih-Khan E, Trieu Y, Bruyere $\mathrm{H}$, Stewart DA and Bahlis NJ. Influence of cytogenetics in patients with relapsed or refractory multiple myeloma treated with lenalidomide plus dexamethasone: adverse effect of deletion 17p13. Blood. 2009; 114(3):522-525.

35. Avet-Loiseau H, Gerson F, Magrangeas F, Minvielle S, Harousseau JL and Bataille R. Rearrangements of the c-myc oncogene are present in $15 \%$ of primary human multiple myeloma tumors. Blood. 2001; 98(10):3082-3086.

36. Shou Y, Martelli ML, Gabrea A, Qi Y, Brents LA, Roschke A, Dewald G, Kirsch IR, Bergsagel PL and Kuehl WM. Diverse karyotypic abnormalities of the c-myc locus associated with c-myc dysregulation and tumor progression in multiple myeloma. Proc Natl Acad Sci U S A. 2000; 97(1):228-233.

37. Chng WJ, Huang GF, Chung TH, Ng SB, Gonzalez-Paz N, Troska-Price T, Mulligan G, Chesi M, Bergsagel PL and Fonseca R. Clinical and biological implications of MYC activation: a common difference between MGUS and newly diagnosed multiple myeloma. Leukemia. 2011; 25(6):10261035.

38. Greil R, Fasching B, Loidl P and Huber H. Expression of the c-myc proto-oncogene in multiple myeloma and chronic lymphocytic leukemia: an in situ analysis. Blood. 1991; 78(1):180-191.

39. Greco C, D’Agnano I, Vitelli G, Vona R, Marino M, Mottolese M, Zuppi C, Capoluongo E and Ameglio F. c-MYC deregulation is involved in melphalan resistance of multiple myeloma: role of PDGF-BB. Int J Immunopathol Pharmacol. 2006; 19(1):67-79.

40. Lonial S, Mitsiades CS and Richardson PG. Treatment options for relapsed and refractory multiple myeloma. Clin Cancer Res. 2011; 17(6):1264-1277.

41. Kumar SK, Therneau TM, Gertz MA, Lacy MQ, Dispenzieri A, Rajkumar SV, Fonseca R, Witzig TE, Lust JA, Larson DR, Kyle RA and Greipp PR. Clinical course of patients with relapsed multiple myeloma. Mayo Clin Proc. 2004; 79(7):867-874.

42. Chang-Yew Leow C, Gerondakis S and Spencer A. MEK inhibitors as a chemotherapeutic intervention in multiple myeloma. Blood Cancer J. 2013; 3:e105.

43. Popovic R and Licht JD. MEK and MAF in myeloma therapy. Blood. 2011; 117(8):2300-2302.

44. Boyd KD, Ross FM, Chiecchio L, Dagrada GP, Konn ZJ,
Tapper WJ, Walker BA, Wardell CP, Gregory WM, Szubert AJ, Bell SE, Child JA, Jackson GH, Davies FE and Morgan GJ. A novel prognostic model in myeloma based on cosegregating adverse FISH lesions and the ISS: analysis of patients treated in the MRC Myeloma IX trial. Leukemia. 2012; 26(2):349-355.

45. Hanamura I, Stewart JP, Huang Y, Zhan F, Santra M, Sawyer JR, Hollmig K, Zangarri M, Pineda-Roman M, van Rhee F, Cavallo F, Burington B, Crowley J, Tricot G, Barlogie B and Shaughnessy JD, Jr. Frequent gain of chromosome band 1q21 in plasma-cell dyscrasias detected by fluorescence in situ hybridization: incidence increases from MGUS to relapsed myeloma and is related to prognosis and disease progression following tandem stemcell transplantation. Blood. 2006; 108(5):1724-1732.

46. Inoue J, Otsuki T, Hirasawa A, Imoto I, Matsuo Y, Shimizu $\mathrm{S}$, Taniwaki $\mathrm{M}$ and Inazawa J. Overexpression of PDZK1 within the 1q12-q22 amplicon is likely to be associated with drug-resistance phenotype in multiple myeloma. Am J Pathol. 2004; 165(1):71-81.

47. Shaughnessy J. Amplification and overexpression of CKS1B at chromosome band $1 \mathrm{q} 21$ is associated with reduced levels of p27Kip1 and an aggressive clinical course in multiple myeloma. Hematology. 2005; 10 Suppl 1:117126.

48. Kocher O, Comella N, Tognazzi $\mathrm{K}$ and Brown LF. Identification and partial characterization of PDZK1: a novel protein containing PDZ interaction domains. Lab Invest. 1998; 78(1):117-125.

49. Kool M, de Haas M, Scheffer GL, Scheper RJ, van Eijk MJ, Juijn JA, Baas F and Borst P. Analysis of expression of cMOAT (MRP2), MRP3, MRP4, and MRP5, homologues of the multidrug resistance-associated protein gene (MRP1), in human cancer cell lines. Cancer Res. 1997; 57(16):35373547.

50. Zhan F, Colla S, Wu X, Chen B, Stewart JP, Kuehl WM, Barlogie B and Shaughnessy JD, Jr. CKS1B, overexpressed in aggressive disease, regulates multiple myeloma growth and survival through SKP2- and p27Kip1-dependent and -independent mechanisms. Blood. 2007; 109(11):49955001.

51. Shi L, Wang S, Zangari M, Xu H, Cao TM, Xu C, Wu Y, Xiao F, Liu Y, Yang Y, Salama M, Li G, Tricot G and Zhan F. Over-expression of CKS1B activates both MEK/ ERK and JAK/STAT3 signaling pathways and promotes myeloma cell drug-resistance. Oncotarget. 2010; 1(1):2233.

52. Chang H, Ning Y, Qi X, Yeung J and Xu W. Chromosome $1 \mathrm{p} 21$ deletion is a novel prognostic marker in patients with multiple myeloma. Br J Haematol. 2007; 139(1):51-54.

53. Walker BA, Wardell CP, Melchor L, Hulkki S, Potter NE, Johnson DC, Fenwick K, Kozarewa I, Gonzalez D, Lord CJ, Ashworth A, Davies FE and Morgan GJ. Intraclonal heterogeneity and distinct molecular mechanisms characterize the development of $\mathrm{t}(4 ; 14)$ and $\mathrm{t}(11 ; 14)$ 
myeloma. Blood. 2012; 120(5):1077-1086.

54. Pollett JB, Trudel S, Stern D, Li ZH and Stewart AK. Overexpression of the myeloma-associated oncogene fibroblast growth factor receptor 3 confers dexamethasone resistance. Blood. 2002; 100(10):3819-3821.

55. Grand EK, Chase AJ, Heath C, Rahemtulla A and Cross NC. Targeting FGFR3 in multiple myeloma: inhibition of t(4;14)-positive cells by SU5402 and PD173074. Leukemia. 2004; 18(5):962-966.

56. Chapman MA, Lawrence MS, Keats JJ, Cibulskis K, Sougnez C, Schinzel AC, Harview CL, Brunet JP, Ahmann GJ, Adli M, Anderson KC, Ardlie KG, Auclair D, Baker A, Bergsagel PL, Bernstein BE, et al. Initial genome sequencing and analysis of multiple myeloma. Nature. 2011; 471(7339):467-472.

57. Egan JB, Shi CX, Tembe W, Christoforides A, Kurdoglu A, Sinari S, Middha S, Asmann Y, Schmidt J, Braggio E, Keats JJ, Fonseca R, Bergsagel PL, Craig DW, Carpten JD and Stewart AK. Whole-genome sequencing of multiple myeloma from diagnosis to plasma cell leukemia reveals genomic initiating events, evolution, and clonal tides. Blood. 2012; 120(5):1060-1066.

58. Hideshima T, Bergsagel PL, Kuehl WM and Anderson KC. Advances in biology of multiple myeloma: clinical applications. Blood. 2004; 104(3):607-618.

59. Kuehl WM and Bergsagel PL. Molecular pathogenesis of multiple myeloma and its premalignant precursor. J Clin Invest. 2012; 122(10):3456-3463.

60. Moreaux J, Klein B, Bataille R, Descamps G, Maiga S, Hose D, Goldschmidt H, Jauch A, Reme T, Jourdan M, Amiot $\mathrm{M}$ and Pellat-Deceunynck C. A high-risk signature for patients with multiple myeloma established from the molecular classification of human myeloma cell lines. Haematologica. 2011; 96(4):574-582.

61. Decaux O, Lode L, Magrangeas F, Charbonnel C, Gouraud W, Jezequel P, Attal M, Harousseau JL, Moreau P, Bataille R, Campion L, Avet-Loiseau H and Minvielle S. Prediction of survival in multiple myeloma based on gene expression profiles reveals cell cycle and chromosomal instability signatures in high-risk patients and hyperdiploid signatures in low-risk patients: a study of the Intergroupe Francophone du Myelome. J Clin Oncol. 2008; 26(29):4798-4805.

62. Jiang A, Reece D and Chang H. Genomic stratification of multiple myeloma treated with novel agents. Leuk Lymphoma. 2012; 53(2):202-207.

63. Drach J, Ackermann J, Fritz E, Kromer E, Schuster R, Gisslinger H, DeSantis M, Zojer N, Fiegl M, Roka S, Schuster J, Heinz R, Ludwig H and Huber H. Presence of a p53 gene deletion in patients with multiple myeloma predicts for short survival after conventional-dose chemotherapy. Blood. 1998; 92(3):802-809.

64. Avet-Loiseau H, Attal M, Moreau P, Charbonnel C, Garban F, Hulin C, Leyvraz S, Michallet M, Yakoub-Agha I, Garderet L, Marit G, Michaux L, Voillat L, Renaud
M, Grosbois B, Guillerm G, et al. Genetic abnormalities and survival in multiple myeloma: the experience of the Intergroupe Francophone du Myelome. Blood. 2007; 109(8):3489-3495.

65. Chang H, Qi C, Yi QL, Reece D and Stewart AK. p53 gene deletion detected by fluorescence in situ hybridization is an adverse prognostic factor for patients with multiple myeloma following autologous stem cell transplantation. Blood. 2005; 105(1):358-360.

66. Xiong W, Wu X, Starnes S, Johnson SK, Haessler J, Wang S, Chen L, Barlogie B, Shaughnessy JD, Jr. and Zhan F. An analysis of the clinical and biologic significance of TP53 loss and the identification of potential novel transcriptional targets of TP53 in multiple myeloma. Blood. 2008; 112(10):4235-4246.

67. Galm O, Herman JG and Baylin SB. The fundamental role of epigenetics in hematopoietic malignancies. Blood Rev. 2006; 20(1):1-13.

68. Rush LJ and Plass C. Alterations of DNA methylation in hematologic malignancies. Cancer Lett. 2002; 185(1):1-12.

69. Feinberg AP and Vogelstein B. Hypomethylation distinguishes genes of some human cancers from their normal counterparts. Nature. 1983; 301(5895):89-92.

70. Brown R and Strathdee G. Epigenomics and epigenetic therapy of cancer. Trends Mol Med. 2002; 8(4 Suppl):S43-48.

71. Rossi D, Capello D, Gloghini A, Franceschetti S, Paulli M, Bhatia K, Saglio G, Vitolo U, Pileri SA, Esteller M, Carbone A and Gaidano G. Aberrant promoter methylation of multiple genes throughout the clinico-pathologic spectrum of B-cell neoplasia. Haematologica. 2004; 89(2):154-164.

72. Braggio E, Maiolino A, Gouveia ME, Magalhaes R, Souto Filho JT, Garnica M, Nucci M and Renault IZ. Methylation status of nine tumor suppressor genes in multiple myeloma. Int J Hematol. 2010; 91(1):87-96.

73. Seidl S, Ackermann J, Kaufmann H, Keck A, Nosslinger T, Zielinski CC, Drach J and Zochbauer-Muller S. DNAmethylation analysis identifies the E-cadherin gene as a potential marker of disease progression in patients with monoclonal gammopathies. Cancer. 2004; 100(12):25982606.

74. Galm O, Wilop S, Reichelt J, Jost E, Gehbauer G, Herman JG and Osieka R. DNA methylation changes in multiple myeloma. Leukemia. 2004; 18(10):1687-1692.

75. Galm O, Yoshikawa H, Esteller M, Osieka R and Herman JG. SOCS-1, a negative regulator of cytokine signaling, is frequently silenced by methylation in multiple myeloma. Blood. 2003; 101(7):2784-2788.

76. Bollati V, Fabris S, Pegoraro V, Ronchetti D, Mosca L, Deliliers GL, Motta V, Bertazzi PA, Baccarelli A and Neri A. Differential repetitive DNA methylation in multiple myeloma molecular subgroups. Carcinogenesis. 2009; 30(8):1330-1335. 
77. Mateos MV, Garcia-Sanz R, Lopez-Perez R, Moro MJ, Ocio E, Hernandez J, Megido M, Caballero MD, FernandezCalvo J, Barez A, Almeida J, Orfao A, Gonzalez M and San Miguel JF. Methylation is an inactivating mechanism of the p16 gene in multiple myeloma associated with high plasma cell proliferation and short survival. Br J Haematol. 2002; 118(4):1034-1040.

78. Takada S, Morita K, Hayashi K, Matsushima T, Sawamura $\mathrm{M}$, Murakami $\mathrm{H}$ and Nojima Y. Methylation status of fragile histidine triad (FHIT) gene and its clinical impact on prognosis of patients with multiple myeloma. Eur $\mathrm{J}$ Haematol. 2005; 75(6):505-510.

79. Chim CS, Kwong YL, Fung TK and Liang R. Methylation profiling in multiple myeloma. Leuk Res. 2004; 28(4):379385.

80. Walker BA, Wardell CP, Chiecchio L, Smith EM, Boyd KD, Neri A, Davies FE, Ross FM and Morgan GJ. Aberrant global methylation patterns affect the molecular pathogenesis and prognosis of multiple myeloma. Blood. 2011; 117(2):553-562.

81. Kaiser MF, Johnson DC, Wu P, Walker BA, Brioli A, Mirabella F, Wardell CP, Melchor L, Davies FE and Morgan GJ. Global methylation analysis identifies prognostically important epigenetically inactivated tumor suppressor genes in multiple myeloma. Blood. 2013; 122(2):219-226.

82. Heuck CJ, Mehta J, Bhagat T, Gundabolu K, Yu Y, Khan S, Chrysofakis G, Schinke C, Tariman J, Vickrey E, Pulliam N, Nischal S, Zhou L, Bhattacharyya S, Meagher $\mathrm{R}, \mathrm{Hu} \mathrm{C}$, et al. Myeloma is characterized by stage-specific alterations in DNA methylation that occur early during myelomagenesis. J Immunol. 2013; 190(6):2966-2975.

83. Christoph Heuck JM, Joseph Tariman, Natalie Pulliam, Yiting Yu,Tushar D. Bhagat, Sangeeta Nischal, Richard Meagher, Caroline Y. Hu, Amit Verma and Seema B. Singhal. Epigenomic Profiling of Multiple Myeloma Shows Widespread Stage Specific Alterations In DNA Methylation That Occur Early During Myelomagenesis. ASH congress. 2010; Abstract No. 784

84. Nojima M, Maruyama R, Yasui H, Suzuki H, Maruyama Y, Tarasawa I, Sasaki Y, Asaoku H, Sakai H, Hayashi $\mathrm{T}$, Mori M, Imai K, Tokino $\mathrm{T}$, Ishida $\mathrm{T}$, Toyota $\mathrm{M}$ and Shinomura Y. Genomic screening for genes silenced by DNA methylation revealed an association between RASD1 inactivation and dexamethasone resistance in multiple myeloma. Clin Cancer Res. 2009; 15(13):4356-4364.

85. Smith EM, Boyd K and Davies FE. The potential role of epigenetic therapy in multiple myeloma. Br J Haematol. 2010; 148(5):702-713.

86. Richardson PG, Mitsiades CS, Laubach JP, Hajek R, Spicka I, Dimopoulos MA, Moreau P, Siegel DS, Jagannath S and Anderson KC. Preclinical data and early clinical experience supporting the use of histone deacetylase inhibitors in multiple myeloma. Leuk Res. 2013; 37(7):829-837.

87. Hajek R, Siegel D, Orlowski RZ, Ludwig H, Palumbo
A and Dimopoulos MA. The Role of Hdac Inhibitors in Patients with Relapsed/Refractory Multiple Myeloma. Leuk Lymphoma. 2013.

88. Maiso P, Carvajal-Vergara X, Ocio EM, Lopez-Perez R, Mateo G, Gutierrez N, Atadja P, Pandiella A and San Miguel JF. The histone deacetylase inhibitor LBH589 is a potent antimyeloma agent that overcomes drug resistance. Cancer Res. 2006; 66(11):5781-5789.

89. Ken Maes EM, Els Van Valckenborgh, Ivan Van Riet, Karin Vanderkerken, and Elke De Bruyne. Epigenetic Modulating Agents as a New Therapeutic Approach in Multiple Myeloma. Cancers. 2013; 5:430-461.

90. CS Chim TK Fung, R Liang. Disruption of INK4/CDK/Rb cell cycle pathway by gene hypermethylation in multiple myeloma and MGUS. Leukemia. 2003; 17:2533-2535.

91. Epstein J, Xiao HQ and Oba BK. P-glycoprotein expression in plasma-cell myeloma is associated with resistance to VAD. Blood. 1989; 74(3):913-917.

92. Sonneveld P, Schoester M and de Leeuw K. Clinical modulation of multidrug resistance in multiple myeloma: effect of cyclosporine on resistant tumor cells. J Clin Oncol. 1994; 12(8):1584-1591.

93. Cornelissen JJ, Sonneveld P, Schoester M, Raaijmakers HG, Nieuwenhuis HK, Dekker AW and Lokhorst HM. MDR-1 expression and response to vincristine, doxorubicin, and dexamethasone chemotherapy in multiple myeloma refractory to alkylating agents. J Clin Oncol. 1994; 12(1):115-119.

94. Grogan TM, Spier CM, Salmon SE, Matzner M, Rybski J, Weinstein RS, Scheper RJ and Dalton WS. P-glycoprotein expression in human plasma cell myeloma: correlation with prior chemotherapy. Blood. 1993; 81(2):490-495.

95. Dalton WS, Crowley JJ, Salmon SS, Grogan TM, Laufman LR, Weiss GR and Bonnet JD. A phase III randomized study of oral verapamil as a chemosensitizer to reverse drug resistance in patients with refractory myeloma. A Southwest Oncology Group study. Cancer. 1995; 75(3):815-820.

96. Friedenberg WR, Rue M, Blood EA, Dalton WS, Shustik C, Larson RA, Sonneveld P and Greipp PR. Phase III study of PSC-833 (valspodar) in combination with vincristine, doxorubicin, and dexamethasone (valspodar/VAD) versus $\mathrm{VAD}$ alone in patients with recurring or refractory multiple myeloma (E1A95): a trial of the Eastern Cooperative Oncology Group. Cancer. 2006; 106(4):830-838.

97. Yang HH, Ma MH, Vescio RA and Berenson JR. Overcoming drug resistance in multiple myeloma: the emergence of therapeutic approaches to induce apoptosis. J Clin Oncol. 2003; 21(22):4239-4247.

98. Buda G, Maggini V, Galimberti S, Martino A, Giuliani N, Morabito F, Genestreti G, Iacopino P, Rizzoli V, Barale R, Rossi AM and Petrini M. MDR1 polymorphism influences the outcome of multiple myeloma patients. Br J Haematol. 2007; 137(5):454-456.

99. Drain S, Flannely L, Drake MB, Kettle P, Orr N, Bjourson 
AJ, Catherwood MA and Alexander HD. Multidrug resistance gene expression and ABCB1 SNPs in plasma cell myeloma. Leuk Res. 2011; 35(11):1457-1463.

100. Buda G, Ricci D, Huang CC, Favis R, Cohen N, Zhuang SH, Harousseau JL, Sonneveld P, Blade J and Orlowski RZ. Polymorphisms in the multiple drug resistance protein 1 and in P-glycoprotein 1 are associated with time to event outcomes in patients with advanced multiple myeloma treated with bortezomib and pegylated liposomal doxorubicin. Ann Hematol. 2010; 89(11):1133-1140.

101. O’Connor R, Ooi MG, Meiller J, Jakubikova J, Klippel S, Delmore J, Richardson P, Anderson K, Clynes M, Mitsiades CS and O'Gorman P. The interaction of bortezomib with multidrug transporters: implications for therapeutic applications in advanced multiple myeloma and other neoplasias. Cancer Chemother Pharmacol. 2013; 71(5):1357-1368.

102. Hawley TS, Riz I, Yang W, Wakabayashi Y, Depalma L, Chang YT, Peng W, Zhu J and Hawley RG. Identification of an ABCB1 (P-glycoprotein)-positive carfilzomibresistant myeloma subpopulation by the pluripotent stem cell fluorescent dye CDy1. Am J Hematol. 2013; 88(4):265272.

103. Raaijmakers MH, de Grouw EP, Heuver LH, van der Reijden BA, Jansen JH, Scheffer G, Scheper RJ, de Witte $\mathrm{TJ}$ and Raymakers RA. Impaired breast cancer resistance protein mediated drug transport in plasma cells in multiple myeloma. Leuk Res. 2005; 29(12):1455-1458.

104. Turner JG, Gump JL, Zhang C, Cook JM, Marchion D, Hazlehurst L, Munster P, Schell MJ, Dalton WS and Sullivan DM. ABCG2 expression, function, and promoter methylation in human multiple myeloma. Blood. 2006; 108(12):3881-3889.

105. Zhou W, Yang Y, Xia J, Wang H, Salama ME, Xiong W, $\mathrm{Xu} \mathrm{H}$, Shetty S, Chen T, Zeng Z, Shi L, Zangari M, Miles $R$, Bearss D, Tricot $G$ and Zhan F. NEK2 induces drug resistance mainly through activation of efflux drug pumps and is associated with poor prognosis in myeloma and other cancers. Cancer Cell. 2013; 23(1):48-62.

106. Saha MN, Qiu L and Chang H. Targeting p53 by small molecules in hematological malignancies. J Hematol Oncol. 2013; 6:23.

107. Vogelstein B and Kinzler KW. Cancer genes and the pathways they control. Nat Med. 2004; 10(8):789-799.

108. Farnebo M, Bykov VJ and Wiman KG. The p53 tumor suppressor: a master regulator of diverse cellular processes and therapeutic target in cancer. Biochem Biophys Res Commun. 2010; 396(1):85-89.

109. Vousden KH and Prives C. Blinded by the Light: The Growing Complexity of p53. Cell. 2009; 137(3):413-431.

110. Avet-Loiseau H, Li JY, Godon C, Morineau N, Daviet A, Harousseau JL, Facon T and Bataille R. P53 deletion is not a frequent event in multiple myeloma. Br J Haematol. 1999; 106(3):717-719.
111. Chng WJ, Price-Troska T, Gonzalez-Paz N, Van Wier S, Jacobus S, Blood E, Henderson K, Oken M, Van Ness B, Greipp P, Rajkumar SV and Fonseca R. Clinical significance of TP53 mutation in myeloma. Leukemia. 2007; 21(3):582-584.

112. Piette J, Neel H and Marechal V. Mdm2: keeping p53 under control. Oncogene. 1997; 15(9):1001-1010.

113. Rayburn E, Zhang R, He J and Wang H. MDM2 and human malignancies: expression, clinical pathology, prognostic markers, and implications for chemotherapy. Curr Cancer Drug Targets. 2005; 5(1):27-41.

114. Elnenaei MO, Gruszka-Westwood AM, A'Hernt R, Matutes E, Sirohi B, Powles R and Catovsky D. Gene abnormalities in multiple myeloma; the relevance of TP53, MDM2, and CDKN2A. Haematologica. 2003; 88(5):529-537.

115. Cocker HA, Hobbs SM, Tiffin N, Pritchard-Jones K, Pinkerton CR and Kelland LR. High levels of the MDM2 oncogene in paediatric rhabdomyosarcoma cell lines may confer multidrug resistance. Br J Cancer. 2001; 85(11):1746-1752.

116. Wilda M, Bruch J, Harder L, Rawer D, Reiter A, Borkhardt $A$ and Woessmann W. Inactivation of the ARF-MDM2-p53 pathway in sporadic Burkitt's lymphoma in children. Leukemia. 2004; 18(3):584-588.

117. Saha MN, Jiang H, Yang Y, Zhu X, Wang X, Schimmer AD, Qiu L and Chang H. Targeting p53 via JNK pathway: a novel role of RITA for apoptotic signaling in multiple myeloma. PLoS One. 2012; 7(1):e30215.

118. Saha MN, Jiang H, Mukai A and Chang H. RITA inhibits multiple myeloma cell growth through induction of p53mediated caspase-dependent apoptosis and synergistically enhances nutlin-induced cytotoxic responses. Mol Cancer Ther. 2010; 9(11):3041-3051.

119. Saha MN, Jiang H and Chang H. Molecular mechanisms of nutlin-induced apoptosis in multiple myeloma: evidence for p53-transcription-dependent and -independent pathways. Cancer Biol Ther. 2010; 10(6):567-578.

120. Saha MN, Jiang H, Jayakar J, Reece D, Branch DR and Chang H. MDM2 antagonist nutlin plus proteasome inhibitor velcade combination displays a synergistic antimyeloma activity. Cancer Biol Ther. 2010; 9(11):936-944.

121. Stuhmer T, Chatterjee M, Hildebrandt M, Herrmann P, Gollasch H, Gerecke C, Theurich S, Cigliano L, Manz RA, Daniel PT, Bommert K, Vassilev LT and Bargou RC. Nongenotoxic activation of the p53 pathway as a therapeutic strategy for multiple myeloma. Blood. 2005; 106(10):3609-3617.

122. Chauhan D, Tian Z, Nicholson B, Kumar KG, Zhou B, Carrasco R, McDermott JL, Leach CA, Fulcinniti M, Kodrasov MP, Weinstock J, Kingsbury WD, Hideshima T, Shah PK, Minvielle S, Altun M, et al. A small molecule inhibitor of ubiquitin-specific protease-7 induces apoptosis in multiple myeloma cells and overcomes bortezomib resistance. Cancer Cell. 2012; 22(3):345-358. 
123. Valdez BC, Wang G, Murray D, Nieto Y, Li Y, Shah J, Turturro F, Wang M, Weber DM, Champlin RE, Qazilbash $\mathrm{MH}$ and Andersson BS. Mechanistic studies on the synergistic cytotoxicity of the nucleoside analogs gemcitabine and clofarabine in multiple myeloma: Relevance of p53 and its clinical implications. Exp Hematol. 2013; 41(8):719-730.

124. Ohki R, Nemoto J, Murasawa H, Oda E, Inazawa J, Tanaka $\mathrm{N}$ and Taniguchi T. Reprimo, a new candidate mediator of the p53-mediated cell cycle arrest at the G2 phase. J Biol Chem. 2000; 275(30):22627-22630.

125. Takahashi T, Suzuki M, Shigematsu H, Shivapurkar N, Echebiri C, Nomura M, Stastny V, Augustus M, Wu CW, Wistuba, II, Meltzer SJ and Gazdar AF. Aberrant methylation of Reprimo in human malignancies. Int $\mathrm{J}$ Cancer. 2005; 115(4):503-510.

126. Almazi JG, Mactier S, Best OG, Crossett B, Mulligan SP and Christopherson RI. Fludarabine nucleoside induces accumulations of p53, p63 and p73 in the nuclei of human B-lymphoid cell lines, with cytosolic and mitochondrial increases in p53. Proteomics Clin Appl. 2012; 6(5-6):279290.

127. Nair P, Muthukkumar S, Sells SF, Han SS, Sukhatme VP and Rangnekar VM. Early growth response-1-dependent apoptosis is mediated by p53. J Biol Chem. 1997; 272(32):20131-20138.

128. Yu J, Baron V, Mercola D, Mustelin T and Adamson ED. A network of p73, p53 and Egr1 is required for efficient apoptosis in tumor cells. Cell Death Differ. 2007; 14(3):436-446.

129. Chen L, Wang S, Zhou Y, Wu X, Entin I, Epstein J, Yaccoby S, Xiong W, Barlogie B, Shaughnessy JD, Jr. and Zhan F. Identification of early growth response protein 1 (EGR-1) as a novel target for JUN-induced apoptosis in multiple myeloma. Blood. 2010; 115(1):61-70.

130. Demchenko YN, Glebov OK, Zingone A, Keats JJ, Bergsagel PL and Kuehl WM. Classical and/or alternative NF-kappaB pathway activation in multiple myeloma. Blood. 2010; 115(17):3541-3552.

131. Demchenko YN and Kuehl WM. A critical role for the NFkB pathway in multiple myeloma. Oncotarget. 2010; 1(1):59-68.

132. Braun T, Carvalho G, Fabre C, Grosjean J, Fenaux P and Kroemer G. Targeting NF-kappaB in hematologic malignancies. Cell Death Differ. 2006; 13(5):748-758.

133. Keats JJ, Fonseca R, Chesi M, Schop R, Baker A, Chng WJ, Van Wier S, Tiedemann R, Shi CX, Sebag M, Braggio E, Henry T, Zhu YX, Fogle H, Price-Troska T, Ahmann G, et al. Promiscuous mutations activate the noncanonical NFkappaB pathway in multiple myeloma. Cancer Cell. 2007; 12(2):131-144.

134. Annunziata CM, Davis RE, Demchenko Y, Bellamy W, Gabrea A, Zhan F, Lenz G, Hanamura I, Wright G, Xiao W, Dave S, Hurt EM, Tan B, Zhao H, Stephens O, Santra M, et al. Frequent engagement of the classical and alternative NF-kappaB pathways by diverse genetic abnormalities in multiple myeloma. Cancer Cell. 2007; 12(2):115-130.

135. Klein B. Positioning NK-kappaB in multiple myeloma. Blood. 2010; 115(17):3422-3424.

136. Fabre C, Mimura N, Bobb K, Kong SY, Gorgun G, Cirstea $\mathrm{D}, \mathrm{Hu} \mathrm{Y}$, Minami J, Ohguchi H, Zhang J, Meshulam J, Carrasco RD, Tai YT, Richardson PG, Hideshima $\mathrm{T}$ and Anderson KC. Dual inhibition of canonical and noncanonical NF-kappaB pathways demonstrates significant antitumor activities in multiple myeloma. Clin Cancer Res. 2012; 18(17):4669-4681.

137. Markovina S, Callander NS, O'Connor SL, Kim J, Werndli JE, Raschko M, Leith CP, Kahl BS, Kim K and Miyamoto S. Bortezomib-resistant nuclear factor-kappaB activity in multiple myeloma cells. Mol Cancer Res. 2008; 6(8):13561364.

138. Xiang Y, Remily-Wood ER, Oliveira V, Yarde D, He L, Cheng JQ, Mathews L, Boucher K, Cubitt C, Perez L, Gauthier TJ, Eschrich SA, Shain KH, Dalton WS, Hazlehurst L and Koomen JM. Monitoring a nuclear factorkappaB signature of drug resistance in multiple myeloma. Mol Cell Proteomics. 2011; 10(11):M110 005520.

139. Mjahed H, Girodon F, Fontenay M and Garrido C. Heat shock proteins in hematopoietic malignancies. Exp Cell Res. 2012; 318(15):1946-1958.

140. Mitsiades N, Mitsiades CS, Poulaki V, Chauhan D, Fanourakis G, Gu X, Bailey C, Joseph M, Libermann TA, Treon SP, Munshi NC, Richardson PG, Hideshima T and Anderson KC. Molecular sequelae of proteasome inhibition in human multiple myeloma cells. Proc Natl Acad Sci U S A. 2002; 99(22):14374-14379.

141. Davenport EL, Zeisig A, Aronson LI, Moore HE, Hockley S, Gonzalez D, Smith EM, Powers MV, Sharp SY, Workman P, Morgan GJ and Davies FE. Targeting heat shock protein 72 enhances Hsp90 inhibitor-induced apoptosis in myeloma. Leukemia. 2010; 24(10):1804-1807.

142. Mitsiades CS, Mitsiades NS, McMullan CJ, Poulaki V, Kung AL, Davies FE, Morgan G, Akiyama M, Shringarpure R, Munshi NC, Richardson PG, Hideshima T, Chauhan D, Gu X, Bailey C, Joseph M, et al. Antimyeloma activity of heat shock protein-90 inhibition. Blood. 2006; 107(3):10921100.

143. Chatterjee M, Jain S, Stuhmer T, Andrulis M, Ungethum U, Kuban RJ, Lorentz H, Bommert K, Topp M, Kramer D, Muller-Hermelink HK, Einsele H, Greiner A and Bargou RC. STAT3 and MAPK signaling maintain overexpression of heat shock proteins 90alpha and beta in multiple myeloma cells, which critically contribute to tumor-cell survival. Blood. 2007; 109(2):720-728.

144. Nimmanapalli R, Gerbino E, Dalton WS, Gandhi V and Alsina M. HSP70 inhibition reverses cell adhesion mediated and acquired drug resistance in multiple myeloma. Br J Haematol. 2008; 142(4):551-561. 
145. Duus J, Bahar HI, Venkataraman G, Ozpuyan F, Izban KF, Al-Masri H, Maududi T, Toor A and Alkan S. Analysis of expression of heat shock protein-90 (HSP90) and the effects of HSP90 inhibitor (17-AAG) in multiple myeloma. Leuk Lymphoma. 2006; 47(7):1369-1378.

146. Khong $\mathrm{T}$ and Spencer A. Targeting HSP 90 induces apoptosis and inhibits critical survival and proliferation pathways in multiple myeloma. Mol Cancer Ther. 2011; 10(10):1909-1917.

147. Chauhan D, Li G, Hideshima T, Podar K, Mitsiades C, Mitsiades N, Catley L, Tai YT, Hayashi T, Shringarpure R, Burger R, Munshi N, Ohtake Y, Saxena S and Anderson KC. Hsp27 inhibits release of mitochondrial protein Smac in multiple myeloma cells and confers dexamethasone resistance. Blood. 2003; 102(9):3379-3386.

148. Abe TMaM. The Importance of Notch Signaling in Myeloma Cell-Osteoclast Interactions. BoneKEyOsteovision. 2005; 2(2):7-10.

149. Nefedova Y, Cheng P, Alsina M, Dalton WS and Gabrilovich DI. Involvement of Notch-1 signaling in bone marrow stroma-mediated de novo drug resistance of myeloma and other malignant lymphoid cell lines. Blood. 2004; 103(9):3503-3510.

150. Milner LA. Notch signaling: a key to the pathogenesis of multiple myeloma? Blood. 2004; 103:3253-3254.

151. Xu D, Hu J, De Bruyne E, Menu E, Schots R, Vanderkerken $\mathrm{K}$ and Van Valckenborgh E. D111/Notch activation contributes to bortezomib resistance by upregulating CYP1A1 in multiple myeloma. Biochem Biophys Res Commun. 2012; 428(4):518-524.

152. Houde C, Li Y, Song L, Barton K, Zhang Q, Godwin J, Nand S, Toor A, Alkan S, Smadja NV, Avet-Loiseau H, Lima CS, Miele L and Coignet LJ. Overexpression of the NOTCH ligand JAG2 in malignant plasma cells from multiple myeloma patients and cell lines. Blood. 2004; 104(12):3697-3704.

153. Colombo M, Mirandola L, Platonova N, Apicella L, Basile A, Figueroa AJ, Cobos E, Chiriva-Internati M and Chiaramonte R. Notch-directed microenvironment reprogramming in myeloma: a single path to multiple outcomes. Leukemia. 2013; 27(5):1009-1018.

154. Xu D, Hu J, Xu S, De Bruyne E, Menu E, Van Camp B, Vanderkerken K and Van Valckenborgh E. D111/ Notch activation accelerates multiple myeloma disease development by promoting CD138+ MM-cell proliferation. Leukemia. 2012; 26(6):1402-1405.

155. Ostman A. The tumor microenvironment controls drug sensitivity. Nat Med. 2012; 18(9):1332-1334.

156. Kocemba KA, Groen RW, van Andel H, Kersten MJ, Mahtouk K, Spaargaren M and Pals ST. Transcriptional silencing of the Wnt-antagonist DKK1 by promoter methylation is associated with enhanced Wnt signaling in advanced multiple myeloma. PLoS One. 2012; 7(2):e30359.

157. Chim CS, Pang R, Fung TK, Choi CL and Liang R.
Epigenetic dysregulation of Wnt signaling pathway in multiple myeloma. Leukemia. 2007; 21(12):2527-2536.

158. Derksen PW, Tjin E, Meijer HP, Klok MD, MacGillavry HD, van Oers MH, Lokhorst HM, Bloem AC, Clevers H, Nusse R, van der Neut R, Spaargaren M and Pals ST. Illegitimate WNT signaling promotes proliferation of multiple myeloma cells. Proc Natl Acad Sci U S A. 2004; 101(16):6122-6127.

159. Bjorklund CC, Ma W, Wang ZQ, Davis RE, Kuhn DJ, Kornblau SM, Wang M, Shah JJ and Orlowski RZ. Evidence of a role for activation of Wnt/beta-catenin signaling in the resistance of plasma cells to lenalidomide. J Biol Chem. 2011; 286(13):11009-11020.

160. Kobune M, Chiba H, Kato J, Kato K, Nakamura K, Kawano Y, Takada K, Takimoto R, Takayama T, Hamada H and Niitsu Y. Wnt3/RhoA/ROCK signaling pathway is involved in adhesion-mediated drug resistance of multiple myeloma in an autocrine mechanism. Mol Cancer Ther. 2007; 6(6):1774-1784.

161. Ito T, Ando H, Suzuki T, Ogura T, Hotta K, Imamura Y, Yamaguchi $\mathrm{Y}$ and Handa H. Identification of a primary target of thalidomide teratogenicity. Science. 2010; 327(5971):1345-1350.

162. Lopez-Girona A, Mendy D, Ito T, Miller K, Gandhi AK, Kang J, Karasawa S, Carmel G, Jackson P, Abbasian M, Mahmoudi A, Cathers B, Rychak E, Gaidarova S, Chen $\mathrm{R}$, Schafer $\mathrm{PH}$, et al. Cereblon is a direct protein target for immunomodulatory and antiproliferative activities of lenalidomide and pomalidomide. Leukemia. 2012; 26(11):2326-2335.

163. Zhu YX, Braggio E, Shi CX, Bruins LA, Schmidt JE, Van Wier S, Chang XB, Bjorklund CC, Fonseca R, Bergsagel PL, Orlowski RZ and Stewart AK. Cereblon expression is required for the antimyeloma activity of lenalidomide and pomalidomide. Blood. 2011; 118(18):4771-4779.

164. Heintel D, Rocci A, Ludwig H, Bolomsky A, Caltagirone S, Schreder M, Pfeifer S, Gisslinger H, Zojer N, Jager U and Palumbo A. High expression of cereblon (CRBN) is associated with improved clinical response in patients with multiple myeloma treated with lenalidomide and dexamethasone. Br J Haematol. 2013; 161(5):695-700.

165. Broyl A, Kuiper R, van Duin M, van der Holt B, el Jarari L, Bertsch U, Zweegman S, Buijs A, Hose D, Lokhorst HM, Goldschmidt H and Sonneveld P. High cereblon expression is associated with better survival in patients with newly diagnosed multiple myeloma treated with thalidomide maintenance. Blood. 2013; 121(4):624-627.

166. Egan JB, Kortuem KM, Kurdoglu A, Izatt T, Aldrich J, Reiman R, Phillips L, Baker A, Shi CX, Schmidt J, Liang WS, Craig DW, Carpten JD and Stewart AK. Extramedullary myeloma whole genome sequencing reveals novel mutations in Cereblon, proteasome subunit G2 and the glucocorticoid receptor in multi drug resistant disease. Br J Haematol. 2013; 161(5):748-751.

167. Shiratsuchi M, Muta K, Abe Y, Motomura S, Taguchi 
F, Takatsuki H, Uike N, Umemura T, Nawata H and Nishimura J. Clinical significance of telomerase activity in multiple myeloma. Cancer. 2002; 94(8):2232-2238.

168. Shammas MA, Koley H, Bertheau RC, Neri P, Fulciniti M, Tassone P, Blotta S, Protopopov A, Mitsiades C, Batchu RB, Anderson KC, Chin A, Gryaznov S and Munshi NC. Telomerase inhibitor GRN163L inhibits myeloma cell growth in vitro and in vivo. Leukemia. 2008; 22(7):14101418.

169. Wang ES, Wu K, Chin AC, Chen-Kiang S, Pongracz K, Gryaznov S and Moore MA. Telomerase inhibition with an oligonucleotide telomerase template antagonist: in vitro and in vivo studies in multiple myeloma and lymphoma. Blood. 2004; 103(1):258-266.

170. Weiss C, Uziel O, Wolach O, Nordenberg J, Beery E, Bulvick S, Kanfer G, Cohen O, Ram R, Bakhanashvili M, Magen-Nativ H, Shilo N and Lahav M. Differential downregulation of telomerase activity by bortezomib in multiple myeloma cells-multiple regulatory pathways in vitro and ex vivo. Br J Cancer. 2012; 107(11):1844-1852.

171. Diaz de la Guardia R, Catalina P, Panero J, Elosua C, Pulgarin A, Lopez MB, Ayllon V, Ligero G, Slavutsky I and Leone PE. Expression profile of telomere-associated genes in multiple myeloma. J Cell Mol Med. 2012; 16(12):30093021.

172. Flavia Pichiorri LDLaRIA. MicroRNAs: new players in multiple myeloma. Frontiers in Genetics. 2011; 2(Article 22).

173. Pichiorri F, Suh SS, Ladetto M, Kuehl M, Palumbo T, Drandi D, Taccioli C, Zanesi N, Alder H, Hagan JP, Munker R, Volinia S, Boccadoro M, Garzon R, Palumbo A, Aqeilan RI, et al. MicroRNAs regulate critical genes associated with multiple myeloma pathogenesis. P Natl Acad Sci USA. 2008; 105(35):12885-12890.

174. Konstantinos Dimopoulos PG, Kirsten Grønbæk. Aberrant microRNA expression in multiple myeloma. European Journal of Haematology. 2013; 91:95-105.

175. Kwan Yeung Wong XHaCSC. DNA methylation of microRNA genes in multiple myeloma. Carcinogenesis. 2012; 33(9):1629-1638.

176. Rio-Machin A, Ferreira BI, Henry T, Gomez-Lopez G, Agirre X, Alvarez S, Rodriguez-Perales S, Prosper F, Calasanz MJ, Martinez J, Fonseca R and Cigudosa JC. Downregulation of specific miRNAs in hyperdiploid multiple myeloma mimics the oncogenic effect of $\mathrm{IgH}$ translocations occurring in the non-hyperdiploid subtype. Leukemia. 2013; 27(4):925-931.

177. Munker R, Liu CG, Taccioli C, Alder H and Heerema N. MicroRNA Profiles of Drug-Resistant Myeloma Cell Lines. Acta Haematol-Basel. 2010; 123(4):201-204.

178. Loffler D, Brocke-Heidrich K, Pfeifer G, Stocsits C, Hackermuller J, Kretzschmar AK, Burger R, Gramatzki M, Blumert C, Bauer K, Cvijic H, Ullmann AK, Stadler PF and Horn F. Interleukin-6-dependent survival of multiple myeloma cells involves the Stat3-mediated induction of microRNA-21 through a highly conserved enhancer. Blood. 2007; 110(4):1330-1333.

179. Michael A. Tessel ALB, Nancy L. Krett, Steven T. Rosen, Preethi H. Gunaratne. Role for MicroRNAs in Regulating Glucocorticoid Response and Resistance in Multiple Myeloma. HORM CANC. 2011; 2:182-189.

180. Hao M, Zhang L, An G, Meng H, Han Y, Xie Z, Xu Y, Li C, Yu Z, Chang H and Qiu L. Bone marrow stromal cells protect myeloma cells from bortezomib induced apoptosis by suppressing microRNA-15a expression. Leuk Lymphoma. 2011; 52(9):1787-1794.

181. Hao M, Zhang L, An G, Sui WW, Yu Z, Zou DH, Xu Y, Chang $\mathrm{H}$ and Qiu LG. Suppressing miRNA-15a/-16 expression by interleukin- 6 enhances drug-resistance in myeloma cells. Journal of Hematology \& Oncology. 2011; 4.

182. Misiewicz-Krzeminska I, Sarasquete ME, Quwaider D, Krzeminski P, Ticona FV, Paino T, Delgado M, Aires A, Ocio EM, Garcia-Sanz R, Miguel JFS and Gutierrez NC. Restoration of microRNA-214 expression reduces growth of myeloma cells through positive regulation of P53 and inhibition of DNA replication. Haematologica. 2013; 98(4):640-648.

183. Kumar M, Lu Z, Takwi AAL, Chen W, Callander NS, Ramos KS, Young KH and Li Y. Negative regulation of the tumor suppressor p53 gene by microRNAs. Oncogene. 2011; 30(7):843-853.

184. Schoenhals M, Kassambara A, Veyrune JL, Moreaux J, Goldschmidt H, Hose D and Klein B. Kruppel-like factor 4 blocks tumor cell proliferation and promotes drug resistance in multiple myeloma. Haematologica. 2013; 98(9):14421449.

185. Li QF, Wu CT, Guo Q, Wang H and Wang LS. Sphingosine 1-phosphate induces $\mathrm{Mcl}-1$ upregulation and protects multiple myeloma cells against apoptosis. Biochem Biophys Res Commun. 2008; 371(1):159-162.

186. Li QF, Wu CT, Duan HF, Sun HY, Wang H, Lu ZZ, Zhang QW, Liu HJ and Wang LS. Activation of sphingosine kinase mediates suppressive effect of interleukin-6 on human multiple myeloma cell apoptosis. Br J Haematol. 2007; 138(5):632-639.

187. O'Donnell E and Raje NS. Targeting BRAF in Multiple Myeloma. Cancer Discov. 2013; 3(8):840-842.

188. Hoang B, Zhu L, Shi Y, Frost P, Yan H, Sharma S, Goodglick L, Dubinett S and Lichtenstein A. Oncogenic RAS mutations in myeloma cells selectively induce cox2 expression, which participates in enhanced adhesion to fibronectin and chemoresistance. Blood. 2006; 107(11):4484-4490.

189. Andrulis M, Lehners N, Capper D, Penzel R, Heining C, Huellein J, Zenz T, von Deimling A, Schirmacher P, Ho AD, Goldschmidt H, Neben K and Raab MS. Targeting the BRAF V600E Mutation in Multiple Myeloma. Cancer 
Discov. 2013; 3(8):862-869.

190. Hideshima T, Mitsiades C, Tonon G, Richardson PG and Anderson KC. Understanding multiple myeloma pathogenesis in the bone marrow to identify new therapeutic targets. Nat Rev Cancer. 2007; 7(8):585-598.

191. Manier S, Sacco A, Leleu X, Ghobrial IM and Roccaro AM. Bone marrow microenvironment in multiple myeloma progression. J Biomed Biotechnol. 2012; 2012:157496.

192. Meads MB, Gatenby RA and Dalton WS. Environmentmediated drug resistance: a major contributor to minimal residual disease. Nat Rev Cancer. 2009; 9(9):665-674.

193. Holt RU, Baykov V, Ro TB, Brabrand S, Waage A, Sundan A and Borset M. Human myeloma cells adhere to fibronectin in response to hepatocyte growth factor. Haematologica. 2005; 90(4):479-488.

194. Kuhn DJ, Berkova Z, Jones RJ, Woessner R, Bjorklund CC, Ma W, Davis RE, Lin P, Wang H, Madden TL, Wei C, Baladandayuthapani V, Wang M, Thomas SK, Shah JJ, Weber DM, et al. Targeting the insulin-like growth factor-1 receptor to overcome bortezomib resistance in preclinical models of multiple myeloma. Blood. 2012; 120(16):32603270 .

195. Shain KH and Dalton WS. Cell adhesion is a key determinant in de novo multidrug resistance (MDR): new targets for the prevention of acquired MDR. Mol Cancer Ther. 2001; 1(1):69-78.

196. Shain KH, Landowski TH and Dalton WS. The tumor microenvironment as a determinant of cancer cell survival: a possible mechanism for de novo drug resistance. Curr Opin Oncol. 2000; 12(6):557-563.

197. Chauhan D, Uchiyama H, Akbarali Y, Urashima M, Yamamoto K, Libermann TA and Anderson KC. Multiple myeloma cell adhesion-induced interleukin- 6 expression in bone marrow stromal cells involves activation of NF-kappa B. Blood. 1996; 87(3):1104-1112.

198. Gupta D, Treon SP, Shima Y, Hideshima T, Podar K, Tai YT, Lin B, Lentzsch S, Davies FE, Chauhan D, Schlossman RL, Richardson P, Ralph P, Wu L, Payvandi F, Muller G, et al. Adherence of multiple myeloma cells to bone marrow stromal cells upregulates vascular endothelial growth factor secretion: therapeutic applications. Leukemia. 2001; 15(12):1950-1961.

199. Shain KH, Yarde DN, Meads MB, Huang M, Jove R, Hazlehurst LA and Dalton WS. Beta1 integrin adhesion enhances IL-6-mediated STAT3 signaling in myeloma cells: implications for microenvironment influence on tumor survival and proliferation. Cancer Res. 2009; 69(3):10091015.

200. Chauhan D, Kharbanda S, Ogata A, Urashima M, Teoh G, Robertson M, Kufe DW and Anderson KC. Interleukin-6 inhibits Fas-induced apoptosis and stress-activated protein kinase activation in multiple myeloma cells. Blood. 1997; 89(1):227-234.

201. Hardin J, MacLeod S, Grigorieva I, Chang R, Barlogie
B, Xiao $\mathrm{H}$ and Epstein J. Interleukin-6 prevents dexamethasone-induced myeloma cell death. Blood. 1994; 84(9):3063-3070.

202. Lichtenstein A, Tu Y, Fady C, Vescio R and Berenson J. Interleukin-6 inhibits apoptosis of malignant plasma cells. Cell Immunol. 1995; 162(2):248-255.

203. Catlett-Falcone R, Landowski TH, Oshiro MM, Turkson J, Levitzki A, Savino R, Ciliberto G, Moscinski L, FernandezLuna JL, Nunez G, Dalton WS and Jove R. Constitutive activation of Stat 3 signaling confers resistance to apoptosis in human U266 myeloma cells. Immunity. 1999; 10(1):105115 .

204. Frassanito MA, Cusmai A, Iodice G and Dammacco F. Autocrine interleukin- 6 production and highly malignant multiple myeloma: relation with resistance to drug-induced apoptosis. Blood. 2001; 97(2):483-489.

205. Voorhees PM, Chen Q, Kuhn DJ, Small GW, Hunsucker SA, Strader JS, Corringham RE, Zaki MH, Nemeth JA and Orlowski RZ. Inhibition of interleukin-6 signaling with CNTO 328 enhances the activity of bortezomib in preclinical models of multiple myeloma. Clin Cancer Res. 2007; 13(21):6469-6478.

206. Noborio-Hatano K, Kikuchi J, Takatoku M, Shimizu R, Wada T, Ueda M, Nobuyoshi M, Oh I, Sato K, Suzuki T, Ozaki K, Mori M, Nagai T, Muroi K, Kano Y, Furukawa Y, et al. Bortezomib overcomes cell-adhesion-mediated drug resistance through downregulation of VLA-4 expression in multiple myeloma. Oncogene. 2009; 28(2):231-242.

207. Damiano JS, Cress AE, Hazlehurst LA, Shtil AA and Dalton WS. Cell adhesion mediated drug resistance (CAMDR): role of integrins and resistance to apoptosis in human myeloma cell lines. Blood. 1999; 93(5):1658-1667.

208. Hazlehurst LA, Damiano JS, Buyuksal I, Pledger WJ and Dalton WS. Adhesion to fibronectin via beta1 integrins regulates p27kip1 levels and contributes to cell adhesion mediated drug resistance (CAM-DR). Oncogene. 2000; 19(38):4319-4327.

209. Yanamandra N, Colaco NM, Parquet NA, Buzzeo RW, Boulware D, Wright G, Perez LE, Dalton WS and Beaupre DM. Tipifarnib and bortezomib are synergistic and overcome cell adhesion-mediated drug resistance in multiple myeloma and acute myeloid leukemia. Clin Cancer Res. 2006; 12(2):591-599.

210. Schmidmaier R, Baumann P, Simsek M, Dayyani F, Emmerich B and Meinhardt G. The HMG-CoA reductase inhibitor simvastatin overcomes cell adhesion-mediated drug resistance in multiple myeloma by geranylgeranylation of Rho protein and activation of Rho kinase. Blood. 2004; 104(6):1825-1832.

211. Neri P, Ren L, Azab AK, Brentnall M, Gratton K, Klimowicz AC, Lin C, Duggan P, Tassone P, Mansoor A, Stewart DA, Boise LH, Ghobrial IM and Bahlis NJ. Integrin beta7-mediated regulation of multiple myeloma cell adhesion, migration, and invasion. Blood. 2011; 117(23):6202-6213. 
212. Schmidmaier R, Morsdorf K, Baumann P, Emmerich B and Meinhardt G. Evidence for cell adhesion-mediated drug resistance of multiple myeloma cells in vivo. Int $\mathrm{J}$ Biol Markers. 2006; 21(4):218-222.

213. Hazlehurst LA, Enkemann SA, Beam CA, Argilagos RF, Painter J, Shain KH, Saporta S, Boulware D, Moscinski L, Alsina $\mathrm{M}$ and Dalton WS. Genotypic and phenotypic comparisons of de novo and acquired melphalan resistance in an isogenic multiple myeloma cell line model. Cancer Res. 2003; 63(22):7900-7906.

214. Shain KH, Landowski TH and Dalton WS. Adhesionmediated intracellular redistribution of c-Fas-associated death domain-like IL-1-converting enzyme-like inhibitory protein-long confers resistance to CD95-induced apoptosis in hematopoietic cancer cell lines. J Immunol. 2002; 168(5):2544-2553.

215. Nefedova Y, Landowski TH and Dalton WS. Bone marrow stromal-derived soluble factors and direct cell contact contribute to de novo drug resistance of myeloma cells by distinct mechanisms. Leukemia. 2003; 17(6):1175-1182.

216. Markovina S, Callander NS, O'Connor SL, Xu G, Shi Y, Leith CP, Kim K, Trivedi P, Kim J, Hematti P and Miyamoto S. Bone marrow stromal cells from multiple myeloma patients uniquely induce bortezomib resistant NFkappaB activity in myeloma cells. Mol Cancer. 2010; 9:176.

217. Wang $X$, Zhang $Z$ and Yao C. Survivin is upregulated in myeloma cell lines cocultured with mesenchymal stem cells. Leuk Res. 2010; 34(10):1325-1329.

218. Romagnoli M, Trichet V, David C, Clement M, Moreau P, Bataille R and Barille-Nion S. Significant impact of survivin on myeloma cell growth. Leukemia. 2007; 21(5):1070-1078.

219. Bjorklund CC, Baladandayuthapani V, Lin HY, Jones RJ, Kuiatse I, Wang H, Yang J, Shah JJ, Thomas SK, Wang M, Weber DM and Orlowski RZ. Evidence of a role for CD44 and cell adhesion in mediating resistance to lenalidomide in multiple myeloma: therapeutic implications. Leukemia. 2013.

220. Tamura H, Ishibashi M, Yamashita T, Tanosaki S, Okuyama N, Kondo A, Hyodo H, Shinya E, Takahashi H, Dong H, Tamada K, Chen L, Dan K and Ogata K. Marrow stromal cells induce B7-H1 expression on myeloma cells, generating aggressive characteristics in multiple myeloma. Leukemia. 2013; 27(2):464-472.

221. Liu J, Hamrouni A, Wolowiec D, Coiteux V, Kuliczkowski K, Hetuin D, Saudemont A and Quesnel B. Plasma cells from multiple myeloma patients express B7-H1 (PDL1) and increase expression after stimulation with IFN\{gamma\} and TLR ligands via a MyD88-, TRAF6-, and MEK-dependent pathway. Blood. 2007; 110(1):296-304.

222. Brito JL, Walker B, Jenner M, Dickens NJ, Brown NJ, Ross FM, Avramidou A, Irving JA, Gonzalez D, Davies FE and Morgan GJ. MMSET deregulation affects cell cycle progression and adhesion regulons in $\mathrm{t}(4 ; 14)$ myeloma plasma cells. Haematologica. 2009; 94(1):78-86.
223. Leich E, Weissbach S, Klein HU, Grieb T, Pischimarov J, Stuhmer T, Chatterjee M, Steinbrunn T, Langer C, Eilers M, Knop S, Einsele H, Bargou R and Rosenwald A. Multiple myeloma is affected by multiple and heterogeneous somatic mutations in adhesion- and receptor tyrosine kinase signaling molecules. Blood Cancer J. 2013; 3:e102.

224. Hurt EM, Wiestner A, Rosenwald A, Shaffer AL, Campo E, Grogan T, Bergsagel PL, Kuehl WM and Staudt LM. Overexpression of c-maf is a frequent oncogenic event in multiple myeloma that promotes proliferation and pathological interactions with bone marrow stroma. Cancer Cell. 2004; 5(2):191-199.

225. Abe M, Hiura K, Wilde J, Shioyasono A, Moriyama K, Hashimoto T, Kido S, Oshima T, Shibata H, Ozaki S, Inoue $\mathrm{D}$ and Matsumoto T. Osteoclasts enhance myeloma cell growth and survival via cell-cell contact: a vicious cycle between bone destruction and myeloma expansion. Blood. 2004; 104(8):2484-2491.

226. Elke De Bruyne EM, Els Van Valckenborgh, Hendrik De Raeve, Ben Van Camp, Ivan Van Riet and Karin Vanderkerken. Myeloma Cells and Their Interactions With the Bone Marrow Endothelial Cells. Current Immunology Reviews. 2007; (3):41-55.

227. Zheng Y, Cai Z, Wang S, Zhang X, Qian J, Hong S, Li H, Wang M, Yang J and Yi Q. Macrophages are an abundant component of myeloma microenvironment and protect myeloma cells from chemotherapy drug-induced apoptosis. Blood. 2009; 114(17):3625-3628.

228. Zheng Y, Yang J, Qian J, Qiu P, Hanabuchi S, Lu Y,WangZ, Liu Z, Li H, He J, Lin P, Weber D, Davis RE, Kwak L, Cai Z and Yi Q. PSGL-1/selectin and ICAM-1/ CD18 interactions are involved in macrophage-induced drug resistance in myeloma. Leukemia. 2013; 27(3):702710.

229. Martin SK, Diamond P, Gronthos S, Peet DJ and Zannettino AC. The emerging role of hypoxia, HIF-1 and HIF-2 in multiple myeloma. Leukemia. 2011; 25(10):1533-1542.

230. Abdi J, Mutis T, Garssen J and Redegeld F. Characterization of the Toll-like receptor expression profile in human multiple myeloma cells. PLoS One. 2013; 8(4):e60671.

231. Jego G, Bataille R, Geffroy-Luseau A, Descamps G and Pellat-Deceunynck C. Pathogen-associated molecular patterns are growth and survival factors for human myeloma cells through Toll-like receptors. Leukemia. 2006; 20(6):1130-1137.

232. Bohnhorst J, Rasmussen T, Moen SH, Flottum M, Knudsen L, Borset M, Espevik T and Sundan A. Toll-like receptors mediate proliferation and survival of multiple myeloma cells. Leukemia. 2006; 20(6):1138-1144.

233. Abdi J, Mutis T, Garssen J and Redegeld F. Stimulation of Toll-like receptor-1/2 combined with Velcade increases cytotoxicity to human multiple myeloma cells. Blood Cancer J. 2013; 3:e119.

234. Brennan SK and Matsui W. Cancer stem cells: controversies 
in multiple myeloma. J Mol Med (Berl). 2009; 87(11):10791085.

235. Ghosh N and Matsui W. Cancer stem cells in multiple myeloma. Cancer Lett. 2009; 277(1):1-7.

236. Matsui W, Huff CA, Wang Q, Malehorn MT, Barber J, Tanhehco Y, Smith BD, Civin CI and Jones RJ. Characterization of clonogenic multiple myeloma cells. Blood. 2004; 103(6):2332-2336.

237. Kirshner J, Thulien KJ, Martin LD, Debes Marun C, Reiman T, Belch AR and Pilarski LM. A unique threedimensional model for evaluating the impact of therapy on multiple myeloma. Blood. 2008; 112(7):2935-2945.

238. Matsui W, Wang Q, Barber JP, Brennan S, Smith BD, Borrello I, McNiece I, Lin L, Ambinder RF, Peacock C, Watkins DN, Huff CA and Jones RJ. Clonogenic multiple myeloma progenitors, stem cell properties, and drug resistance. Cancer Res. 2008; 68(1):190-197.

239. Reghunathan R, Bi C, Liu SC, Loong KT, Chung TH, Huang $\mathrm{G}$ and Chng WJ. Clonogenic Multiple Myeloma Cells have Shared stemness Signature Assocuated with Patient Survival. Oncotarget. 2013; 4(8):1230-1240.

240. Pilarski LM, Seeberger K, Coupland RW, Eshpeter A, Keats JJ, Taylor BJ and Belch AR. Leukemic B cells clonally identical to myeloma plasma cells are myelomagenic in NOD/SCID mice. Exp Hematol. 2002; 30(3):221-228.

241. Pilarski LM and Belch AR. Clonotypic myeloma cells able to xenograft myeloma to nonobese diabetic severe combined immunodeficient mice copurify with CD34 (+) hematopoietic progenitors. Clin Cancer Res. 2002; 8(10):3198-3204

242. Bergsagel PL, Smith AM, Szczepek A, Mant MJ, Belch $\mathrm{AR}$ and Pilarski LM. In multiple myeloma, clonotypic B lymphocytes are detectable among CD19+ peripheral blood cells expressing CD38, CD56, and monotypic Ig light chain. Blood. 1995; 85(2):436-447.

243. Hosen N, Matsuoka Y, Kishida S, Nakata J, Mizutani Y, Hasegawa K, Mugitani A, Ichihara H, Aoyama Y, Nishida S, Tsuboi A, Fujiki F, Tatsumi N, Nakajima H, Hino M, Kimura $\mathrm{T}$, et al. CD138-negative clonogenic cells are plasma cells but not B cells in some multiple myeloma patients. Leukemia. 2012; 26(9):2135-2141.

244. Fenghuang Zhan WZ, Maurizio Zangari, Hongwei Xu, MD, MS and Guido J. Tricot. ALDH1 Activity Identifies Chemotherapy-Resistant Multiple Myeloma Stem Cells. ASH congress. 2011; Abstract 990.

245. Yang Y, Shi J, Tolomelli G, Xu H, Xia J, Wang H, Zhou W, Zhou Y, Das S, Gu Z, Levasseur D, Zhan F and Tricot G. RARalpha2 expression confers myeloma stem cell features. Blood. 2013; 122(8):1437-1447.

246. Peacock CD, Wang Q, Gesell GS, Corcoran-Schwartz IM, Jones E, Kim J, Devereux WL, Rhodes JT, Huff CA, Beachy PA, Watkins DN and Matsui W. Hedgehog signaling maintains a tumor stem cell compartment in multiple myeloma. Proc Natl Acad Sci U S A. 2007;
104(10):4048-4053.

247. Bhardwaj G, Murdoch B, Wu D, Baker DP, Williams KP, Chadwick K, Ling LE, Karanu FN and Bhatia M. Sonic hedgehog induces the proliferation of primitive human hematopoietic cells via BMP regulation. Nat Immunol. 2001; 2(2):172-180.

248. Merchant AA and Matsui W. Targeting Hedgehog--a cancer stem cell pathway. Clin Cancer Res. 2010; 16(12):31303140 .

249. Brennan SK, Wang Q, Tressler R, Harley C, Go N, Bassett E, Huff CA, Jones RJ and Matsui W. Telomerase inhibition targets clonogenic multiple myeloma cells through telomere length-dependent and independent mechanisms. PLoS One. 2010; 5(9).

250. Gentile M, Recchia AG, Mazzone C, Lucia E, Vigna E and Morabito F. Perspectives in the treatment of multiple myeloma. Expert Opin Biol Ther. 2013; 13 Suppl 1:S1-22.

251. Misso G, Zappavigna S, Castellano M, De Rosa G, Di Martino MT, Tagliaferri P, Tassone P and Caraglia M. Emerging pathways as individualized therapeutic target of multiple myeloma. Expert Opin Biol Ther. 2013; 13 Suppl 1:S95-109.

252. Usmani SZ and Chiosis G. HSP90 inhibitors as therapy for multiple myeloma. Clin Lymphoma Myeloma Leuk. 2011; 11 Suppl 1:S77-81.

253. Leung-Hagesteijn C, Erdmann N, Cheung G, Keats JJ, Stewart AK, Reece DE, Chung KC and Tiedemann RE. Xbp1s-negative tumor B cells and pre-plasmablasts mediate therapeutic proteasome inhibitor resistance in multiple myeloma. Cancer Cell. 2013; 24(3):289-304. 